\title{
Bacterial chemotaxis: a way forward to aromatic compounds biodegradation
}

\author{
Fiaz Ahmad, Daochen Zhu* and Jianzhong Sun *i]
}

\begin{abstract}
Worldwide industrial development has released hazardous polycyclic aromatic compounds into the environment. These pollutants need to be removed to improve the quality of the environment. Chemotaxis mechanism has increased the bioavailability of these hydrophobic compounds to microorganisms. The mechanism, however, is poorly understood at the ligand and chemoreceptor interface. Literature is unable to furnish a compiled review of already published data on up-to-date research on molecular aspects of chemotaxis mechanism, ligand and receptor-binding mechanism, and downstream signaling machinery. Moreover, chemotaxis-linked biodegradation of aromatic compounds is required to understand the chemotaxis role in biodegradation better. To fill this knowledge gap, the current review is an attempt to cover PAHs occurrence, chemical composition, and potential posed risks to humankind. The review will cover the aspects of microbial signaling mechanism, the structural diversity of methyl-accepting chemotaxis proteins at the molecular level, discuss chemotaxis mechanism role in biodegradation of aromatic compounds in model bacterial genera, and finally conclude with the potential of bacterial chemotaxis for aromatics biodegradation.
\end{abstract}

Keywords: Environmental pollution, Motility, Chemoreceptor, Ligand-binding domain, Signaling domain

\section{Background}

Movement is a mandatory phenomenon to sustain life for any living organism. In microorganisms, this movement is a controlled mechanism mediated by a delicate multiprotein system. This movement mechanism helps prokaryotic or eukaryotic microorganisms for temperature regulation, $\mathrm{pH}$ balance, nutrient regulation, evading from unfavorable environments, and moving towards favorable niches. Microorganisms contain specialized structures for movement, i.e., cilia and flagella. Microorganisms typically make a biased random walk [1]. Taxis, on the other hand, is a directed movement by microorganisms. Whenever this movement is in response to a chemical stimulus, it is referred to as chemotaxis $[2,3]$. This kind of microorganism's movement could help in the degradation of environmental pollutants like polycyclic aromatic compounds.

*Correspondence: dczhucn@hotmail.com; jzsun1002@ujs.edu.cn Biofuels Institute, School of Environment and Safety Engineering, Jiangsu University, Zhenjiang, Jiangsu, People's Republic of China
Aromatic compounds (AC) in nature are structurally diverse with single or multiple benzene rings. Polycyclic aromatic hydrocarbons (PAHs) are persistent organic pollutants that are toxic, genotoxic, carcinogenic, and mutagenic to organisms. PAHs are found naturally in plant cell wall structure and are produced artificially by anthropogenic sources. PAHs are aromatic hydrocarbons bearing two or more fused benzene rings in linear, angular, and cluster conformations [4, 5]. PAHs are classified as light and heavy PAHs based on the number of rings found; four rings refer to the former, while those bearing more than four rings refer to the latter category. Heavy PAHs are reported as more stable and toxic than the light PAHs [6]. Carbon and hydrogen are the constituent elements of PAHs bound in a simple-to-complex benzene ring arrangements. This ring arrangement gives PAHs a wide diversity of physical, chemical, and toxicological characteristics [7].

With industrial development, PAHs become ubiquitous contaminants in the environment, especially in soil. Chemical oxidation, bioaccumulation, volatilization, 
photo-oxidation, and adsorption to soil particles seem to be the possible fate of PAHs released into the environment. However, increased awareness about adverse effects on humans and the ecosystem has prompted an intensive search for effective remediation processes to clean up contaminated sites. The principle degradation process in the soil is degradation by microbial transformation [8]. Bioremediation techniques represent a valuable, environmentally friendly alternative for the decontamination of this material.

Several bacteria use these aromatic compounds as carbon and energy sources for growth. Therefore, bacterial biodegradation pathways for these compounds are an interesting topic of research. Moreover, biological treatments also comply with the EU Landfill Directive [9]. Microbial degradation and transformation are the leading processes for PAHs removal. It is reported that after a period of acclimation, bacteria can successfully degrade low molecular weight (LMW) PAHs. Nevertheless, the efficiency is limited for higher molecular weight (HMW) PAHs [10].

In addition to PAHs, the lignin component of lignocellulosic biomass is a significant contribution towards natural aromatic compounds production. Lignin is a three-dimensional polymer of aromatic compounds: $p$-coumaryl, coniferyl, and sinapyl alcohols, with crosslinking via $\mathrm{C}-\mathrm{O}-\mathrm{C}$ ether bonds and $\mathrm{C}-\mathrm{C}$ bonds. Lignin is the most abundant organic compound next to cellulose. Aromatic compounds make one-quarter of the plant biomass [11]. Plant monolignols are synthesized via the shikimic acid pathway [12], while microorganisms produce aromatic compounds via malonic acid pathway [13]. Plants, major producers of $\mathrm{AC}$, are unable to degrade these compounds due to having no degradation pathway.

On the contrary, microorganisms do possess degrading pathways. Recently, proteomic analysis of Bacillus ligniniphilus L1 indicated that methyl-accepting chemotaxis protein (MCP) and MCP sensory transducer were up-regulated 5.5- and 10-fold when lignin was the sole carbon source during degradation. The study suggested the potential involvement of chemotaxis proteins in the aromatic compound's biodegradation [14].

Chemotaxis is believed to increase the bioavailability and biodegradation efficiency where PAHs pollutants are heterogeneously distributed either in soils or in water. $[15,16]$. Chemotaxis is a well-established field. A plethora of research has been published on chemotaxis, indicating the potential of this approach to new insights in the chemotaxis process for PAHs bioremediation. However, the literature regarding biodegradation of PAHs and its possible linkage to chemotaxis needs a comprehensive review to establish the link between chemotaxis, bioavailability, and in turn, biodegradation of aromatic compounds. In this review, the authors attempt to provide a brief overview of PAHs concerning their occurrence in the geosphere, production mechanisms, and potentially pose risks to the environment and humans. Furthermore, much of the focus will be on up-to-date research progress in the chemotaxis field, insights on molecular mechanisms involved, the chemistry behind the binding mechanism of model aromatic compounds, and metabolic pathways linked to chemotaxis.

\section{Occurrence, chemical composition, and potential risks of PAHs}

PAHs are mostly colorless, white, or pale-yellow organic solids or vaporous form compounds. These are omnipresent with worldwide recognition as priority pollutants in soil sediments, water sources, and atmosphere [17]. PAHs are chemically related several hundred individual chemical compounds that occur in group form instead of single compounds with varied structural configuration and toxicity levels. PAHs production is through natural and anthropogenic routes. Carbonization process (mineral oil and coal formation) and incomplete combustion of organic compounds in an insufficient amount of oxygen and high moisture content are the examples for natural and anthropogenic PAHs production, respectively $[18,19]$. An increase in PAHs molecular weight results in electrochemical stability, an increase in PAHs carcinogenic index, persistency, and biodegradation resistivity. Therefore, understanding the source of PAHs will be much helpful in determining the route of PAHs in the environment and possible bioremediation strategies.

The most common pathways of PAHs production are pyrogenic and petrogenic, while a less known formation route is biological [17]. Formation temperature plays the differentiation role between the pyrogenic and petrogenic PAHs. PAHs formed under moderate temperatures $\left(100-300{ }^{\circ} \mathrm{C}\right)$ through the slow and long-term process associated with fossil fuels are referred to as petrogenic. Widespread sources of petrogenic PAHs are oil spills, storage tank leaks, and release of gasoline or motor oil in transportation. PAHs formed under high-temperature conditions $\left(>700{ }^{\circ} \mathrm{C}\right)$ in low-to-zero oxygen conditions are termed pyrogenic, their production process is much rapid than the former. This implies that formation temperature is in direct relation to PAHs types formed and associated complexities [20]. For example, $1 \mathrm{~g}$ of tobacco yields $44 \mathrm{ng}$ at $400{ }^{\circ} \mathrm{C}$ while at $1000{ }^{\circ} \mathrm{C}$, it yields $183,500 \mathrm{ng}$ of benzo[a]pyrene (BaP) [21]. Readers are referred to the work of Lima et al. [20] to understand the factors affecting the combustion-derived PAHs and their environmental fate. Another way to identify the PAHs source is based on the ratio of molecular weight; the ratio of $\mathrm{LMW} / \mathrm{HMW}<1$ indicates pyrogenic source while the 
ratio $>1$ specifies petrogenic source [22]. Plants and bacteria form some PAHs during the degradation of vegetative matter, yet the biological route of PAHs formation is not well known [17].

The chemical structure of PAHs is simple (naphthalene-two rings) to complex (coronene-seven rings) benzene ring arrangement. This arrangement results in physical, chemical, and toxicological characteristics [7]. Hydrophobicity and bioaccumulation tendency enhance with an increase in PAHs molecule size and structure angularity. It must be noted that the detrimental effects of PAHs also increase with a concomitant increase in molecular size. It is found that alkylated PAHs generated by diagenetic processes are much toxic than the parent compounds, though, alkylated PAHs compounds exist mutually with parent compounds. Alkylated PAHs are considered environmentally persistent than their parent compounds.

PAHs are toxic with pronounced effects on human health. In that context, the US Environmental Protection Agency (US EPA) issued a list of priority PAHs to tackle this. Several researchers studied the level of PAHs in urban areas and assessed their potential risk impact on human health. It is generally accepted that urban areas contain higher PAHs concentration owing to vehicular emissions, natural gas combustion, and petrol emissions [23-25]. Wang et al. [26] studied the critical concentrations of PAHs in urban soils of the Nanjing district of China. The authors divided the risk into four levels (equivalent values of benzo $[a]$ pyrene (BaPeq)): $<70 \mathrm{ng} \mathrm{g}^{-1}, 70-700 \mathrm{ng} \mathrm{g}^{-1}, 700-7000 \mathrm{ng} \mathrm{g}^{-1}$, and $>7000 \mathrm{ng} \mathrm{g}^{-1}$. The authors found Nanjing at below critical level (level 3) by this standard. Furthermore, they reported that population density and black carbon content proved to be the leading factors in PAHs level increase. In a recent study, Wu et al. [27] discussed the report of cooking-related PAHs emission to personal health in three commercial cooking places (western fast food restaurant kitchens, Chinese cafeteria kitchens, and street food carts) for possible cancer risk. The data revealed that fast-food restaurants and Chinese cafeteria workers exposed to less PAHs concentration compare to street food carts. The study concluded that a less effective exhaust system results in high aldehyde exposure in street food cart workers rendering a higher tendency to cancer risk.

PAH degradation in soil by augmentation with specific isolated bacteria or fungus has been documented in various studies. Scopulariopsis brevicaulis PZ-4 isolated from an aged PAH-contaminated soil was found to have the ability to degrade PAHs. In a PAH-contaminated soil, Scopulariopsis brevicaulis PZ-4 removed $77 \%$ of total PAHs, and the highest removal of PAHs occurred for phenanthrene (89\%) and benzo(a)pyrene (75\%) after incubation for 28 days.

The above discussion indicated that PAHs are much toxic and have potential risk hazards to human life and the surrounding environment. Therefore, they need to be mineralized to basic building blocks. However, since PAHs are recognized as persistent pollutants, so degradation is very to negligibly slow. Though several bacteria have been isolated to degrade PAHs, the degradation rate is much lower than the production of PAHs from different sources. The major problem, in this regard, is their bioavailability to microorganisms. Microorganism's signaling mechanism could play a vital role. In the next section, we will elaborate on the signaling mechanism of microorganism and how it could help in the biodegradation of PAHs.

\section{Signaling transduction mechanisms in bacteria}

PAHs are hydrophobic with low water solubility and a higher tendency to bind with organic matter present in the soil. This adsorption makes their availability limited to microorganisms for degradation. Yet with these properties, several strains have been screened with the ability to degrade PAHs, utilizing as carbon and energy source [28]. PAHs degrading bacteria adjust themselves in the PAHs-rich soils by several genetic modifications and increasing their population size [29]. It is believed that chemotaxis has played a vital role in the availability of the PAHs to microorganisms [30]. In microorganisms, three well-developed sophisticated mechanisms are presented, where environmental stimuli are sensed by them, and the microorganism's molecular machinery undertakes a reaction. Furthermore, chemotactic bacteria overcome mass-transfer limitations that impede the biotransformation process [31]. Here, we will shed light on the signal transduction mechanisms exhibited by the most prokaryotic organisms and establish their link to PAHs biodegradation.

Microorganisms are dynamic and complex cell systems. Several factors control their population density, diversity, and distribution in the environment. How these factors impulse a stimulus, what the underlying mechanisms are, and how microorganisms perceive these stimuli and respond have long fascinated the researchers. The advancement in molecular biology and bioinformatics has unfolded that microorganisms bear a complex mechanism. This inherent mechanism in microorganisms is responsible for sensing and afterward triggering a due cellular response to various environmental cues such as light, nutrients, temperature, osmolarity, and adherable surfaces, etc. [32].

Three kinds of signal transduction mechanisms are present in microorganisms, i.e., one-component system, 
two-component system, and chemotaxis system that is a specialized form of a two-component system. PAHs are toxic compounds, and their absorption to bacterial membrane above a threshold level could result in the death of cells [33]. Therefore, a delicate balance between PAHs compounds absorption by the cell membrane and degradation by microorganisms is inevitable. Chemotactic behavior or transcriptional-level regulation plays a critical role in maintaining this balance [34]. Genomic analysis revealed that the signaling system lies between the two-component system and the chemotaxis system [35]. Signal transduction pathways are considered to play an active role in biodegradation and availability of aromatic compounds, ranging from a single-ring to multiple-ring PAHs, to microorganisms [36]. Therefore, it is quite essential to understand the molecular and functional basis of these signal transduction mechanisms to degrade aromatic compounds effectively. Furthermore, understanding the functional characterization of genes involved in triggering these transduction mechanisms could help us to link with the degradation pathways that will revolutionize the PAHs degradation by genetic engineering.

\section{One-component system}

The signal transduction system is not a simple process. The one-component system is considered the simplest, consisting of only a single cytosolic protein. One-component systems are believed to be evolutionarily older than two-component systems. The genomic analysis of 145 prokaryotic genomes suggested that one-component systems are distributed among bacteria and archaea [37]. Based on genomic analysis, the authors speculated that the evolutionary history of two-component systems roots to one-component systems based on three observations: (a) simpler modular design, (b) domain repertoire diversity, and (c) distribution of one-component systems in prokaryotes.

One-component systems typically use two separate domains, i.e., sensory (input) and regulatory (output). Input domains are constituted by small molecule-binding motifs, while helix-turn-helix DNA-binding motifs are output domains [37]. It was found that signal transduction in most prokaryotes consists of single proteins (one-component systems). The single protein lacks phosphotransfer domains that are the critical domain in two-component systems. A typical example of a onecomponent system is a ligand-binding transcriptional regulator. The one-component system also shows variations in terms of domains; only one sensory and regulatory domain per protein [38] or multiple sensory and regulatory domains in a single protein [39]. Readers are further directed to the work of Ulrich et al. [37] for a better understanding of one-component systems.

A classic example of the one-component system is the transcriptional regulators that control catabolic pathways responsible for aromatic compounds degradation. Aromatic compounds biodegradation in microbial communities is controlled by 11 different transcriptional regulators, as explained by Rodriguez et al. [40].

\section{Two-component system}

The term two-component system was coined around 1986 to describe a novel class of regulatory systems in bacteria [41]. It is considered a highly sophisticated signaling mechanism with a highly modular design. It consists of a membrane-bound histidine-kinase (conserved kinase core) with extracellular input domain and cytosolic response-regulator protein (regulatory domain). Environmental stimuli are sensed by HK that modulates activities and transfers the phosphoryl group to the receiver domain of response regulator. The response regulator contains aspartate residue, a phosphoryl group acceptor. This phosphorylation results in downstream activities at the effector/output domain that dictates the specific response. The regulatory output by the majority of response regulators is mediated at the transcriptional level [42]. Readers are referred to an excellent review by Stock et al. [43] for the detailed comprehension of phosphorylation chemistry, structure, and function of histidine kinase and structure and function of response regulator and effector domain; while to grasp genomic evolution and molecular mechanism of the two-component regulatory system, respectively, reviews by Capra and Laub [44] and Zschiedrich et al. [45] are recommended.

\section{Chemotaxis system}

Chemotaxis, a multiprotein system, is witnessed in most prokaryotic species and assumed to be evolved from a two-component system that controls prokaryotic transcription. In bacteria, sensory recognition of a chemical gradient triggers a molecular signal transduction cascade. This results in a modulation of flagellar activity, directing the movement of the bacteria either towards or away from stimulatory molecules depending upon favorable and unfavorable conditions $[46,47]$. Chemotaxis pathways in prokaryotes are known to vary depending upon inhabiting conditions. The main components of the chemotaxis signal transduction pathways are conserved and are made up of the ternary complex between methylaccepting chemotaxis proteins such as the sensor protein, and the adaptor protein.

The foundation of microbial chemotactic response mechanism is based on $E$. coli that are extensively studied 
[48, 49]. The chemotactic repertoire of E. coli is quite simple. The signaling cascade is based on five chemoreceptors. These co-factor proteins are named Tar, Tsr, Trg, Tap, and Aer. Tar and Tsr are amino acid receptors, whereas Trg, Tap, and Aer are more specific receptors for sugars, dipeptides, and redox potential [50]. Chemoreceptors are subject to vary per microbial species depending upon their lifestyle and metabolic diversity. Bacteria with the capability to inhabit in multiple and variable environments could contain 5 times more chemoreceptors than bacteria that strive in specific environmental conditions. In some species even up to 60 chemoreceptors have been identified [51, 52]. Bacteria with chemosensory signaling capability contain, on average, 14 chemoreceptor genes [51]. The location of chemoreceptors is also subject to variations. It could be within the cytoplasm or membrane-bound. In E. coli, Tar, Tsr, Trg, and Tap are contained in periplasmic 4 helix binding ligand-binding domain (LBD) while Aer is present in the PAS domain that lies inside cytoplasm [53]. The five cofactor proteins make a signaling complex bearing three components: ligand-binding domain, activity state, and methylation state. The biochemical and structural study of $E$. coli is beyond the scope of this review. The readers are referred to already published reviews [54-56].

Chemotaxis is also based on sensory limits of the receptors, adaptation mechanism, and dynamic range of the chemoreceptors. Bacterial receptors sense environmental stimulus, ligands, and retain in their memory for temporal comparison to make further decisions about chemotaxis. Ligand concentrations limit the sensitivity of the receptors. In this regard, the sensing limits of receptors established by Berg \& Purcell back in 1977 based on diffusion and binding and unbinding of ligands to receptors still hold validity [57]. Ligands concentration and receptors saturation play a vital role in the dynamic range of the chemoreceptors. In a recent study, Tena-Garitaonaindia et al. [58] studied halophilic bacterium Halomonas anticariensis $\mathrm{FP} 35^{\mathrm{T}}$ for chemotaxis and reported that bacteria showed chemotaxis up to $500 \mathrm{ppm}$ of phenol with optimum degradation while it shows chemorepulsion towards higher concentration of $10,000 \mathrm{ppm}$.

Interestingly, receptors can discriminate between ligands concentrations that further could be enhanced by adaptation mechanism [59]. Methylation plays a crucial role in the dynamic range of the chemoreceptors. Increased methylation favors the receptors binding state that ultimately affects the kinase activity and ligand-binding affinity. Methylation system functions by methylation and demethylation of receptors on the specific glutamate residues, respectively, by methyltransferase (CheR) and methylesterase (CheB) [60]. It is interesting to note that the methylation level controls the chemotactic (Che) proteins in the signal transduction network. There are different Che proteins available, including CheA, CheY, CheW, CheZ, CheR, and CheB. Each Che protein has a unique and specific role in transferring the external stimuli to the biomechanical motor for the movement of the cell. The methylation system also gives a short-term memory to the bacterial cell that enables them to detect concentration changes. The methylation system seems to control the transduction network activity by modifying the bacterial behavior to swim along or tumble and reorient [2].

Emerging pieces of evidence suggest that homologous signal transduction pathways regulate not only chemotaxis, but also several other cellular functions in various bacterial species [61]. The chemotaxis signaling pathway of $E$. coli is the best understood and is considered independent of metabolism. Membrane-bound receptor clusters in E. coli cells sense external attractants and repellents. However, literature furnishes reports that chemotaxis could be metabolism dependent and independent in other bacteria.

\section{Structural diversity and binding mechanism in MCPs}

The structural characterization of MCPs is as crucial as understanding the specificity and mode of ligand-binding mechanisms in chemoreceptors. Binding can be categorized as specific and non-specific binding. Unbound ligand concentration and affinity of the binding site are central in this categorization. Since the structure of the protein determines its function. Therefore, the structural characterization of MCPs seems to have pivotal importance in signal transduction mechanisms. Figure 1a indicates the structural components of a typical MCP, while Fig. $1 \mathrm{~b}$ depicts the chemotaxis mechanism in response to aromatic compounds detection and downstream processing. Functional characterization of MCPs could reveal about their role in degradation pathways. Ligand binding capacity of chemoreceptors is vital for the regulation of biological functions in microorganisms. Here, an attempt is made to structurally characterize MCPs that have a role in chemotaxis towards aromatic compounds and their biodegradation pathways.

With the interplay of engineering, biophysical, biomolecular sciences, and bioinformatics, scientists have developed sophisticated tools to visualize transduction mechanisms at the molecular level. Chemoreceptors are transmembrane proteins; it was found that MCPs are of different architecture with different topologies and types of sensor domains. Common MCPs are composed of extended helical bundles. The cytosolic domain comprises two components: histidine kinase adenylyl cyclase (HAMP) domain and methyl-accepting domain based on an adaptation and signaling sub-domain [62]. 


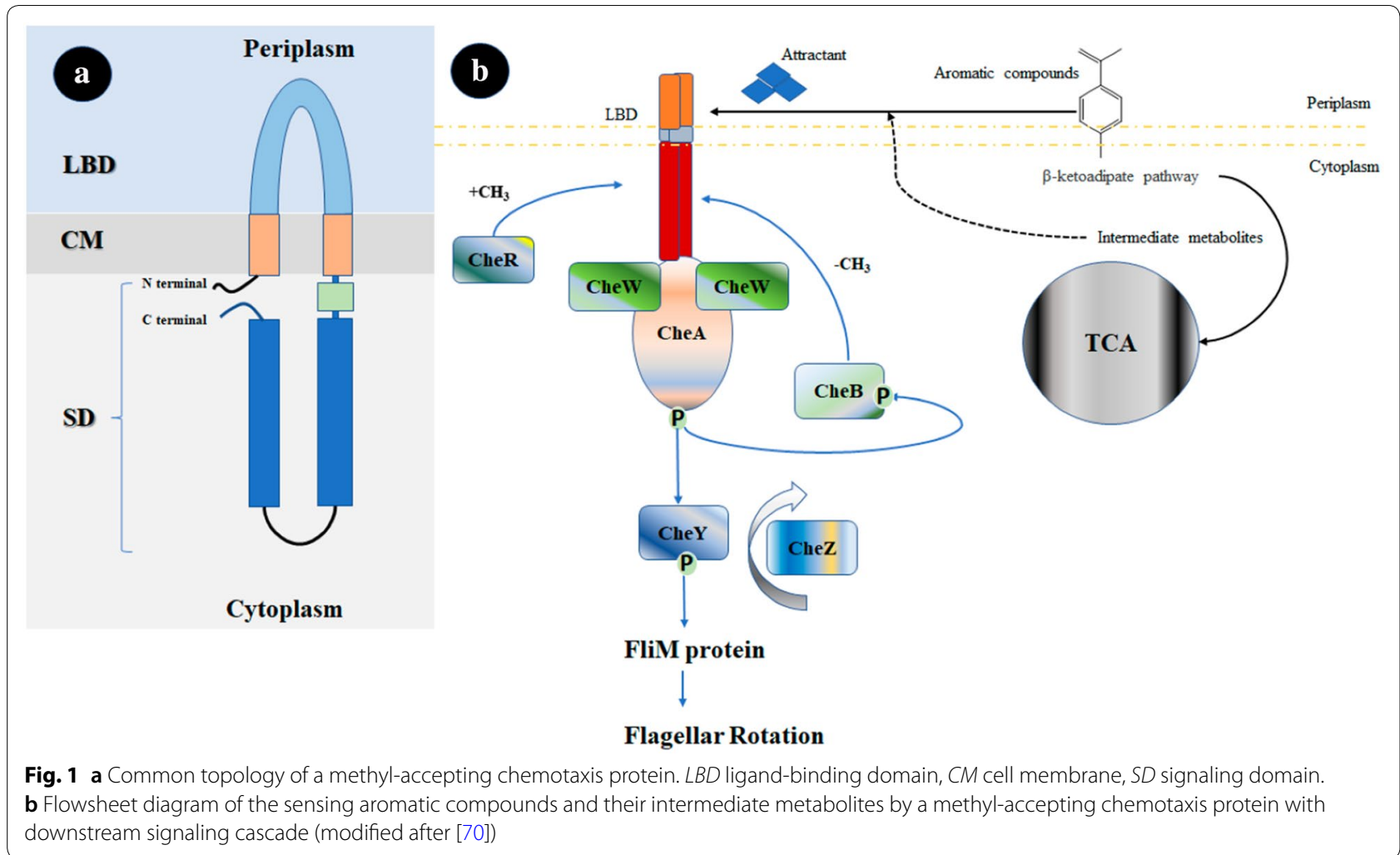

Furthermore, evolutionary genomics and comparative genomics analysis of several hundred bacterial species testify that MCPs have seven distinct classes of cytoplasmic signaling domains [62]. The HAMP domain starts from the transmembrane helices and links to the N-terminal helices of the methyl-accepting domain. Ferris and his team explained this as a universal signal converter in the molecular machinery of the cell. The signal converter translates different kinds of signal inputs into conformational changes via rotating its helices in the downstream domains. The authors proposed this mechanism as a 'cogwheel model' [63]. Almost each MCP indeed contains HAMP and an adaptation domain [62].

The three different signal transduction mechanisms share sensory domains for signal recognition. Sensor domains are classified based on size: Cluster I (about 150 amino acids) and Cluster II (approx. 250 amino acids). Per-ARNT-Sim (PAS), (cyclases/histidine kinases associated sensory extracellular) CHASE, GAF, and TarH sensor domains belong to Cluster I. [51]. About $40 \%$ of chemoreceptors possess Cluster II domains that are mostly un-annotated. Wuichet and fellows [64] suggested that un-annotated domains could either be not recognized due to having low sensitivity or novel and not present in the database. Ulrich et al. [65] developed and managed a database, namely 'Microbial
Signal Transduction (MIST) Database', which furnishes researchers with comprehensive information about microbial genomes with predicted signal transduction properties. The database contains information on 125,000 + genomes, 13 million contigs, 516 million genes, and 100 million unique protein sequences (the website was accessed on 30-08-2019).

Chemotaxis occurs based on: (a) direct signal recognition of chemoeffectors by the chemoreceptors; (b) indirect signal recognition that is exclusively studied in $E$. coli. Central to the chemotaxis system is a two-component regulatory system such as histidine kinase (CheA), the response regulator (CheY), and several auxiliary proteins. Chemoeffectors bind directly or indirectly to the sensor domains of periplasmic receptors. When an unliganded chemoreceptor (MCP) is bound to a chemo effector, CheA becomes activated with autophosphorylation. This binding induces a shift in the equilibrium between the conformations of the cytoplasmic signaling domain. The signaling domain promotes or represses the autophosphorylation activity of CheA, thereby controlling the autophosphorylation [50]. In the next phase, the autophosphorylation of the CheA transfers a phosphoryl group to the response regulator (CheY). It forms a CheY$\mathrm{P}$ complex that diffuses to a flagellar motor and binds to FliM protein. This process increases the probability of a 
clockwise rotation. On the contrary, CheZ is the protein responsible for the dephosphorylation of CheA to reverse this mechanism. In this way, a balance of the chemotaxis process is maintained by the molecular machinery of bacteria.

Chemotactic bacteria possess an adaptation mechanism that is important in the chemotactic swimming of bacteria towards a chemical gradient. This mechanism allows them to make temporal comparisons of the chemical conditions in the environment as they swim to respond to chemical gradients [66, 67]. The adaptation process is supported by two enzymes, methyltransferase CheR and methylesterase CheB. The methylation of the chemoreceptors governed by CheR causes the associated CheA kinases to become more active. While feedback is provided by $\mathrm{CheB}$ phosphorylation through CheA that increases CheB activity [68], this adaptation mechanism is not as simple as explained in E. coli, but adaptation systems are subject to change depending upon bacterial species diversity [69].

\section{Chemotaxis-linked degradation of aromatic compounds}

Microbial chemotaxis towards aromatic compounds appears to have been recorded for decades [71, 72]. Intensive research on chemotaxis toward aromatic compounds has been conducted with Pseudomonas species [71, 73, 74], Burkholderia species [75], and Comamonas species [76].

Aromatic compounds are structurally diverse with single to multiple benzene rings. Degradation of these aromatics to basic building blocks (carbon and hydrogen) is usually carried out via a limited number of intermediates like benzoate or catechol. The intermediate compounds are subsequently channeled to the tricarboxylic acid (TCA) cycle [77]. Therefore, it could be assumed that the degradation of aromatic compounds is divided into upper and lower pathways. The lower pathways have common intermediates; thereby, the combination of upper and lower pathways has broadened the bacterial potential to degrade aromatic compounds [78]. We, hereby, cover aspects of mono- and polycyclic aromatic compounds biodegradation, pathways involved, and establish the link of chemotaxis towards enhanced biodegradation of these compounds.

\section{Monocyclic aromatic hydrocarbons}

Benzene, toluene, ethylbenzene, and o-, $m$-, and $p$-xylene (BTEX) are the major monoaromatic compounds found in groundwater or soil. The major source is leakage from the gasoline and petrochemical industry. BTEX compounds pose a severe threat to all forms of life. Having high solubility, monoaromatic compounds are incredibly mobile in soil and water and readily available to microbial flora. However, owing to hydrophobicity, these compounds are toxic to the cytoplasmic membrane. However, microorganisms have evolved to utilize monoaromatic compounds as sole carbon and energy sources resulting in microbial biodegradation as an energy-efficient, environment-friendly, and low-cost effective strategy to reclaim polluted soils and water. It must be noted that no single pure culture can degrade these pollutants to $\mathrm{CO}_{2}$ and $\mathrm{H}_{2} \mathrm{O}$. Therefore, mixed microbial communities are necessary for effective degradation. Furthermore, acclimatized microbial communities have a higher degradation rate than non-acclimatized ones. Aerobic and anaerobic pathways can accompany biodegradation. This review is, however, more focused on degradation by aerobic pathways linked to chemotaxis as an effective degradation strategy. For detailed comprehension of anaerobic degradation of aromatic compounds, readers are referred to some excellent review papers [79-82].

In aerobic degradation, BTEX primary transformation is carried out by multi-component enzymatic systems such as mono-oxygenases and di-oxygenases. As the name indicated, the former uses one oxygen atom while the latter uses two oxygen atoms to cleave the aromatic ring resulting, respectively, in pyrocatechols and 2-hydroxy-substituted compounds. Intermediate products are subsequently entered into the TCA cycle via different pathways. Five different aerobic degradation pathways have been identified for toluene degradation. A detailed discussion of the involved biochemical pathways is beyond the scope of the current review, however. Readers are referred to $[34,83]$ for in-depth comprehension.

An array of microorganisms under different genera has been studied for BTEX degradation (Table 1). The genus Pseudomonas of $\gamma$-Proteobacteria is probably the most studied one. The members are widespread colonizers with 272 species (http://www.bacterio.net/pseud omonas.html). The strains are capable of adapting to various environmental conditions. The specific genetic makeup of bacterial strains is responsible for degrading various organic compounds, including common biogenic aromatics and anthropogenic aromatic compounds. The versatile degradation capability makes Pseudomonas genus ubiquitous in soil, plant surface, animals, and even humans [84]. Of various strains, P. putida KT2440 (a variant of $P$. putida $\mathrm{mt}-2$ ) is presumably the best laboratorycharacterized pseudomonad.

Chemotaxis towards aromatic compounds by $P$. putida PRS2000 was first reported back in 1984. But, the mechanisms involved in this phenomenon remained ambiguous until complete genome sequencing, bioinformatic tool development, and advanced techniques in molecular biology. A range of aromatic compounds is degraded by the Pseudomonads employing 14 different peripheral 
Table 1 Chemotaxis-linked degradation of environmental pollutants

\begin{tabular}{|c|c|c|c|c|c|}
\hline Pollutant group & Bacterial strain & Chemoattractant & Degradation pathway & Chemotaxis & References \\
\hline \multirow[t]{12}{*}{$\begin{array}{l}\text { Simple and/or single-ring } \\
\text { aromatic hydrocarbons }\end{array}$} & Pseudomonas putida F1 & $\begin{array}{l}\text { Benzene, toluene, trichloro- } \\
\text { ethylene }\end{array}$ & Meta ring-cleavage & + & {$[75]$} \\
\hline & Pseudomonas sp KA & Benzene, toluene, xylene & TOL and TOD pathway & N.C. & {$[103]$} \\
\hline & Pseudomonas mendocina KR1 & $\begin{array}{l}\text { Benzene, toluene, m-xylene, } \\
\text { p-xylene }\end{array}$ & $\mathrm{TOL}$ & N.C. & {$[104]$} \\
\hline & Pseudomonas putida AY-10 & $\begin{array}{l}\text { Benzene, toluene, ethylben- } \\
\text { zene, xylene }\end{array}$ & N.D & N.C. & {$[105]$} \\
\hline & Pseudomonas putida mt-2 & Succinate, m-xylene & TOL & N.C. & {$[106]$} \\
\hline & $\begin{array}{l}\text { Pseudomonas putida CCMI } \\
\quad 852\end{array}$ & Benzene, toluene, xylene & TOL & N.C. & {$[107]$} \\
\hline & Pseudomonas stutzeri OX1 & Toluene, o-xylene & TOL & N.C. & {$[108]$} \\
\hline & $\begin{array}{l}\text { Burkholderia fungorum } \\
\text { FLU100 }\end{array}$ & $\begin{array}{l}\text { Toluene, benzene, mono- } \\
\text { halogen benzene }\end{array}$ & Ortho-cleavage pathway & N.C. & {$[109]$} \\
\hline & $\begin{array}{l}\text { Cupriavidus metallidurans } \\
\mathrm{CH} 34\end{array}$ & $\begin{array}{l}\text { Benzene, toluene, } \\
\text { o-xylene, p-cymene, } \\
\text { 3-hydroxybenzoate, } \\
\text { 4-hydroxybenzoate, } \\
\text { 3-hydroxyphenylacetate, } \\
\text { 4-hydroxyphenylacetate, } \\
\text { homogentisate, catechol, } \\
\text { naphthalene, and 2-ami- } \\
\text { nophenol }\end{array}$ & Meta-cleavage pathway & N.C. & {$[110]$} \\
\hline & $\begin{array}{l}\text { Pseudomonas thivervalensis } \\
\text { MAH1 }\end{array}$ & $\begin{array}{l}\text { Benzene, toluene, ethylben- } \\
\text { zene, and xylene }\end{array}$ & N.D. & N.C. & {$[111]$} \\
\hline & Pseudomonas putida F1 & $\begin{array}{l}\text { Vanillate, vanillin, 4-hydroxy- } \\
\text { benzoate, benzoate, } \\
\text { protocatechuate, quinate, } \\
\text { shikimate }\end{array}$ & $\beta$-Ketoadipate & + & {$[87]$} \\
\hline & $\begin{array}{l}\text { Pseudomonas putida Fu1 } \\
\text { Pseudomonas sp. strain A3 }\end{array}$ & $\begin{array}{l}\text { Furfural, 5-hydroxymethylfur- } \\
\text { fural, furfuryl alcohol, and } \\
\text { 2-furoic acid }\end{array}$ & Aerobic degradation & + & {$[112]$} \\
\hline \multirow[t]{6}{*}{ Nitro-substituents } & Pseudomonas putida PRS2000 & $\begin{array}{l}\text { Benzoate and 4-hydroxyben- } \\
\text { zoate, 3- and 4-nitroben- } \\
\text { zoate }\end{array}$ & $\beta$-Ketoadipate- & + & {$[113]$} \\
\hline & $\begin{array}{l}\text { Pseudomonas. putida TW3 } \\
\text { Pseudomonas sp. strain 4NT }\end{array}$ & $\begin{array}{l}\text { 4-Nitrotoluene, 4-nitroben- } \\
\text { zoate, aminobenzoate } \\
\text { isomers }\end{array}$ & $\beta$-Ketoadipate- & + & {$[113]$} \\
\hline & Pseudomonas fluorescens KU-7 & 2-Nitrobenzoate & & + & {$[92]$} \\
\hline & Acidovorax sp. strain JS42 & 2-Nitrotoluene & Dioxygenase ring cleavage & + & {$[114]$} \\
\hline & Ralstonia sp. SJ98 & $\begin{array}{l}\text { p-Nitrophenol, 4-nitrocat- } \\
\text { echol, o-nitrobenzoic acid, } \\
\text { and p-nitrobenzoic acid }\end{array}$ & N.D. & + & {$[31]$} \\
\hline & $\begin{array}{l}\text { Pseudomonas sp. strain } \\
\text { WBC-3 }\end{array}$ & $\begin{array}{l}\text { Para-nitrophenol, 4-nitrocat- } \\
\text { echol, and hydroquinone }\end{array}$ & $\beta$-Ketoadipate & + & {$[88]$} \\
\hline \multirow[t]{4}{*}{ Chloro-substituent } & Pseudomonas sp. JHN & 4-Chloro-2-nitrophenol & N.D. & + & {$[115]$} \\
\hline & Pseudomonas sp. JHN & 4-Chloro-3-nitrophenol & N.D. & + & {$[116]$} \\
\hline & Burkholderia sp. SJ98 & $\begin{array}{l}\text { 2-Chloro-4-nitrophenol and } \\
\text { 2-chloro-3-nitrophenol }\end{array}$ & & + & {$[89]$} \\
\hline & $\begin{array}{l}\text { Pseudomonas pseudoalcali- } \\
\text { genes KF707 }\end{array}$ & $\begin{array}{l}\text { Biphenyl, benzoic acid and } \\
\text { chlorobenzoic acids }\end{array}$ & & + & {$[117]$} \\
\hline
\end{tabular}


Table 1 (continued)

\begin{tabular}{|c|c|c|c|c|c|}
\hline Pollutant group & Bacterial strain & Chemoattractant & Degradation pathway & Chemotaxis & References \\
\hline \multirow[t]{6}{*}{$\begin{array}{l}\text { Polycyclic aromatic hydro- } \\
\text { carbons }\end{array}$} & $\begin{array}{l}\text { Pseudomonas putida G7 } \\
\text { Pseudomonas sp. strain NCIB } \\
\text { 9816-4 }\end{array}$ & Naphthalene & Meta-cleavage pathway & + & [118] \\
\hline & Pseudomonas putida RKJ1 & Naphthalene and salicylate & N.D. & + & [119] \\
\hline & $\begin{array}{l}\text { Pseudomonas alcaligenes 8A, } \\
\text { Pseudomonas stutzeri 9A, } \\
\text { and Pseudomonas putida } \\
10 \mathrm{D}\end{array}$ & $\begin{array}{l}\text { Naphthalene and phenan- } \\
\text { threne }\end{array}$ & Ortho-cleavage catechol & + & [120] \\
\hline & Kurthia sp and B. circulans & Naphthalene and anthracene & N.D. & + & [121] \\
\hline & $\begin{array}{l}\text { Halomonas titanicae strain } \\
\text { KHS3 }\end{array}$ & Phenanthrene and phthalate & N.D. & + & [122] \\
\hline & Halomonas sp. KHS3 & $\begin{array}{l}\text { Phenanthrene, fluorene, } \\
\text { naphthalene, phthalate, } \\
\text { salicylic acid, Benzoic acid, } \\
\text { and 4-hydroxybenzoic acid }\end{array}$ & $\begin{array}{l}\beta \text {-Ketoadipate, homogen- } \\
\text { tisate and gentisate } \\
\text { pathways }\end{array}$ & + & [123] \\
\hline
\end{tabular}

N.D. - not determined, N.C. - not conducted

pathways to a few common intermediates, which are funneled to the tricarboxylic acid (TCA) cycle. It is reported that $P$. putida contains 12 out of 14 catabolic pathways that corroborate its colonization in almost every environment. The $\beta$-ketoadipate is the most widely distributed pathway in the degradation of the aromatic compounds. It is beyond the scope of this review to discuss all the assimilation pathways; therefore, readers are referred to a reference entry by Nogales and Diaz [85].

Pseudomonas putida DOT-T1E grows on high concentrations of toluene. It was found that strong chemotaxis towards toluene was due to transmissible plasmid pGRT1 in the DOT-T1E strain. It was further confirmed by sitedirected mutagenesis of two open read frames encoded on pGRT1: ORF72 and ORF97. Quantitative capillary assay confirmed that wild strain showed strong chemotaxis towards toluene while mutant strains deficient in ORF72 and ORF97 barely showed chemotaxis. This implicates that plasmid pGRT1 carries the genes responsible for chemotaxis [86]. Luu et al. [87] reported that $P$. putida F1 is chemotactic towards aromatic compounds (vanillin, vanillate, 4-hydroxybenzoate) that funnel in the $\beta$-ketoadipate pathway. The authors further conclude that 4-hydroxybenzoate permease modulates the chemotactic response by up-taking 4-hydroxybenzoate. Chemotactic machinery in P. putida seems responsible for the metabolism and transport of aromatic compounds across the cell.

Pseudomonas sp. strain WBC-3 utilized methyl parathion or para-nitrophenol (PNP) as the sole source of carbon, nitrogen, and energy. Its chemotactic behaviors towards aromatics were investigated. The results indicated that strain $\mathrm{WBC}-3$ was attracted to multiple aromatic compounds, including metabolizable or transformable substrates PNP, 4-nitrocatechol, and hydroquinone. Disruption of PNP catabolic genes did not affect its chemotactic behaviors with the same substrates, indicating that the chemotactic response in this strain was metabolism-independent. Furthermore, it was shown that strain WBC-3 had a constitutive $\beta$-ketoadipate chemotaxis system responding to a broad range of aromatic compounds. It is different from the inducible $\beta$-ketoadipate chemotaxis described in other Pseudomonas strains [88].

Pseudomonas sp. JHN was found involved in decolorization and biotransformation of 4-chloro-2-nitrophenol (4C2NP) up to a concentration of $0.6 \mathrm{mM}$ with 5-chloro2-methylbenzoxazole as a major metabolite. The capillary and drop plate assays showed a positive chemotactic response towards $4 \mathrm{C} 2 \mathrm{NP}$. The authors further concluded that chemotaxis in strain JHN was metabolism dependent as it did not show chemotaxis towards compounds that it cannot degrade or metabolize. Another bacterial strain Burkholderia sp. SJ98 is chemotactic towards chloro-nitroaromatic compounds: 2-chloro-4-nitrophenol, 2-chloro-3-nitrophenol, 4-chloro-2-nitrophenol, 2-chloro-4-nitrobenzoate, 4-chloro-2-nitrobenzoate, and 5-chloro-2-nitrobenzoate. However, it found to be completely inhibited in the presence of nitroaromatic compounds. But it is independently inducible from its chemotaxis towards succinate [89].

Accelerated degradation of nitrophenols was quantified by the strain SJ98 in a later study by Min et al. on artificially contaminated soil, proving the role of chemotaxis in efficient biodegradation [90]. Members of genus Pseudomonas possess the enormous catabolic 
potential to PAHs with chloro- and nitro-substitutions, and strains have shown positive or negative chemotactic response [91-93]. Biphenyl-utilizing bacteria $P$. putida P106 and Pseudomonas sp. B4 using the oxidative route has shown positive chemotaxis towards biphenyls along with metabolization [94-96]. P. putida PR2000 is also chemotactic towards 3- and 4-chlorobenzoates (CBAs), which are intermediate metabolites of polychlorinated biphenyls [74]. CtpL, an inorganic phosphate receptor, was found responsible for positive chemotaxis towards chloroaniline, anthranilate, 4-aminobenzoate, benzoate, 4-chloronitrobenzene, catechol, and 4-chlorocatechol in Pseudomonas aeruginosa PAO1 [97].

In another study, laboratory model strain Burkholderia xenovorans LB400 was compared with Pseudomonas sp. B4 for motility towards biphenyl and degradation. Though strain LB400 was able to degrade biphenyl, it failed to show mobility. Therefore, chemotactic Pseudomonas sp. B4 showed active degradation than strain L400. The study implicates that chemotaxis has an important phenotypic character for efficient microbial degradation of polychlorinated biphenyls [94].

Genus Comamonas is another genus that has been extensively studied in recent years for chemotaxis linked degradation of aromatic compounds. Species of genus Comamonas are Gram-negative, aerobic, flagellated, and mostly rod-shaped with non-fermentative metabolism. The genus comprises 21 species (http://www.bacterio. net/comamonas.html) that are mostly isolated from soil, mud, and water. Genomic analysis of 34 genomes of 11 different Comamonas sp. revealed that metabolic pathways for energy are well conserved, suggesting their wide distribution in natural and engineered environments [98]. Comamonas are chemoorganotrophic and reported to contribute well in soil bioremediation [99]. Members are active degraders of a wide variety of aromatic compounds.

MIST database contains the full domain architecture for the whole genome of four Comamonas species: Comamonas testosteroni TK102 (18 putative MCP genes), Comamonas kerstersii (25 putative MCP genes), Comamonas serinivorans (1 putative MCP gene), and Comamonas testosteroni CNB-2 (20 putative MCP genes). Among them, C. testosteroni are extensively studied for chemotaxis towards aromatic compounds in recent years [70]. In a recent study, C. testosteroni CNB-1 was studied for aromatic compounds. CNB-1 strain grows on a range of aromatic compounds: vanillate, benzoate, gentisate, 3- and 4-hydroxybenzoate, etc., Huang et al. [76] demonstrated that chemoreceptor MCP2901 of C. testosteroni CNB-1 binds to 9 aromatic compounds to initiate downstream signaling process and cause chemotaxis motility. The results were further consolidated by expressing MCP2901 in chemotaxisdeficient null mutant strain. In this study, the authors further speculated that MCP2901 is responsible for both metabolism-dependent and metabolism-independent chemotaxis towards aromatic compounds. This speculation was based on quantitative RT-PCR of previously characterized MCP2201 and MCP2983 in the presence and absence of aromatic compounds.

It is well debated that chemosensory pathways also regulate and control multiple cellular functions for the survival of microorganisms. Cellular functions include gene regulations and cell cycle progression. C. testosteroni CNB-1 were isolated from a wastewater treatment reactor. For enhanced degradation of organic pollutants, biofilm formation is inevitable that allows better microbial cell aggregation and attachment. To better understand the biofilm formation process, cross-talk between two chemosensory pathways is reported for $C$. testosteroni CNB-1. The strain contains one che gene cluster and one $\mathrm{flm}$ gene cluster; the study showed that seven chemoreceptors contribute to biofilm formation that also mediates chemotaxis [100]. This implicates that chemotaxis genes do have a role in cellular functions that contribute to the biodegradation of aromatic compounds.

Though 21 species of genus Comamonas have been discovered, the literature furnishes chemotaxis and biodegradation of aromatics studies mostly on Comamonas testosteroni. C. testosteroni might have multiple advantages over other species, such as (a) colonization and adaptation in various environmental conditions; (b) no competition with other carbohydrate-degrading microorganisms, and (c) well-elucidated assimilation pathways. Biodegradation capacity of $C$. testosteroni has been enhanced by using synthetic biology tools via creating functional gene circuits to enhance the expression of genes using synthetic and wild-type promoters [101]. Lignite addition in the soil coupled with $C$. testosteroni CCM 7530 inoculation resulted in efficient biodegradation; the authors reported that soil ecotoxicity should be monitored during microbial biodegradation [102].

Though BTEX and other monoaromatic hydrocarbons are extensively studied for biodegradation by several bacterial strains under various genera, chemotaxis-linked degradation of monoaromatic compounds is relatively less studied (Table 1). From the available literature, it can safely be presumed that the genus Pseudomonas has been extensively studied for chemotaxis. The authors have established that chemotaxis plays an essential role in the biodegradation of xenobiotics and pollutant aromatic compounds. Moreover, the microorganisms with chemotactic ability could be successfully applied for the restoration of pollutant soils. However, it must be mentioned that still several aromatic compounds need to be tested 
in the priority pollutant list that requires the researcher's attention.

\section{Polycyclic aromatic hydrocarbons}

PAHs consist of two or more fused benzene rings, i.e., from two rings (naphthalene) up to cluster (pyrene) arrangement. International Union of Pure and Applied Chemistry (IUPAC) reported 35 parent PAHs with more than 100 compounds as substituents. Comprehensive information on PAHs nomenclature and structural organization can be found in the cited literature [124-126]. Having high toxicity as reported earlier in this text, various conventional degradation methods of PAHs are cited in the literature, including electro-ultrasonic remediation [127], thermal incineration [128], landfilling [129], and natural and synthetic surfactants [130, 131]. However, biodegradation of PAHs is gaining much attention due to the extravagant cost of the aforementioned conventional methods and environmental concerns. Therefore, literature also furnishes much information from original research articles $[132,133]$ to review articles $[10,134]$ on PAHs biodegradation. Scopus, a well-recognized database for scientific literature search, generated 406 entries for keywords "naphthalene and biodegradation", accessed on 15/11/2019. It indicates the potential interest of the research community in the biodegradation of PAHs.

Bacterial strains degrading PAHs are taxonomically diverse, belonging to genera Pseudomonas, Mycobacterium, Sphingomonas, Alcaligenes, and Bacillus [135]. Therefore, PAHs degradation mechanisms might not be the same for complete mineralization employed by different strains. It depends upon several factors, including a) PAHs structural configuration, b) isomeric forms, c) different substituted forms from parent PAHs, d) nutritional competition between microbial species, and e) interaction between different microbial communities. Commonly PAHs degradation is initiated by ring hydroxylating dioxygenase [136]. Naphthalene degradation in Pseudomonas putida KD10 follows the metacleavage pathway of catechol [137]. Stenotrophomonas maltophilia C6 possesses multiple degradation pathways for phenanthrene [138]. A complete metabolic pathway for mineralization of chrysene by Pseudoxanthomonas sp. PNK-04 is proposed by Nayak et al. [139]. A comprehensive discussion of metabolic pathways for light and heavy PAHs is not in the scope of this text, however, and the readers are referred to a previously published review [140].

A relatively lesser rate of PAHs biodegradation in the soil is subject to the hydrophobicity of PAHs, leading to slow mass transfer of these compounds to degrading microorganisms. In this respect, the chemotaxis study of microorganisms towards PAHs is invaluable. Though high molecular weight PAHs have been extensively studied (Table 1) for biodegradation, chemotaxis-linked biodegradation of PAHs is relatively less studied.

Naphthalene, being a light PAH, is remarkably studied for chemotaxis-linked biodegradation. Pedit et al. [141] developed a mathematical model to quantify the chemotaxis of $P$. putida G7 towards naphthalene and its degradation. Based on experimental data and simulations, authors conclude that in order to have the same naphthalene degradation rate, initial cell concentration of chemotactic mutant would have to be several orders of magnitude than wild chemotactic P. putida that directly implicate the role of chemotaxis in naphthalene biodegradation. As nonaqueous-phase liquid poses difficulty in the bioremediation of PAHs, therefore, in a later study, Law and Atiken [142] observed naphthalene degradation dissolved in a model nonaqueous-phase liquid by $P$. putida G7 to explore whether chemotaxis has a role in nonaqueous phase liquid or not. Wild-type P. putida G7 increased the desorption and degradation rate relative to non-chemotactic mutant, suggesting the widespread role of chemotaxis mechanism in PAHs degradation under different scenarios.

To further consolidate the concept that chemotaxis does increase the biodegradation of PAHs, Marx and Aitken [16] conducted experiments on P. putida G7 to study naphthalene biodegradation in an aqueous heterogeneous system in a glass capillary tube. The authors reported that the wild strain degraded $90 \%$ naphthalene in $6 \mathrm{~h}$ in comparison to a mutant strain (deficient in chemotaxis) that causes a similar reduction in about $30 \mathrm{~h}$ at similar initial microbial concentration. In another study, Hanzel et al. [143] studied the extent of chemotaxis of $P$. putida G7 along the vapor phase gradient. Surprisingly, vapor-phase naphthalene resulted in repulsion of PpG7, although its concentration was 50-100 times lesser than the aqueous concentration. The authors conclude that gaseous phase naphthalene is possibly toxic to cells resulting in negative chemotaxis.

Surprisingly, PAHs degrading bacterial isolates were discovered from non-contaminated soil; Bisht and coworkers [121] discovered four isolates, namely Kurthia sp., Micrococcus varians, Deinococcus radiodurans, and Bacillus circulans from the rhizosphere of Populus deltoides degrading chrysene, benzene, toluene, xylene, naphthalene, and anthracene. Among these isolates, only Kurthia sp. and B. circulans showed positive chemotaxis towards naphthalene and anthracene.

\section{Microfluidic systems}

Microfluidics is the study of a system that processes small amounts of fluids (micro- to atto-liter) with a dimension 
of one to hundreds of micrometers [144]. Microfluidics development is one of the latest innovations to quantify chemotaxis studies. Microfluidics has revolutionized the bacterial chemotaxis due to unprecedented control the system offers over chemical and physical environments at high spatial and temporal resolution. It offers several advantages, such as low cost, good reproducibility, multifunctionality, energy-saving, and physiologically relevant conditions. Microfluidic devices present key features for studying chemotaxis: (a) precise control over channel geometries and fluid flow; (b) transparency and size of microchannels for measuring concentration gradients of the studied chemicals; (c) direct chemotaxis measurement at individual organism scale level with well-defined chemoeffector gradients.

Chemotaxis in microfluidics is studied under flow and non-flow conditions. Based on these two conditions, various kinds of microfluidic devices have been developed, including a three-inlet parallel-flow device [145], the twoinlet parallel-flow device [146], porous two-inlet parallel flow device [147], and nutrient plume injector [148]. Microfluidic devices for the chemotaxis studies require the right selection of materials and accurately designed and fabricated channels for the construction of microfluidic devices. The materials for microfluidics should have the following characteristics: (a) biological and chemical compatibility with the sample in question; (b) good heat conductor; (c) better optical properties for detection; (d) low-cost fabrication of structure for flow generation or immobilization of biological molecules [149]. Readers are referred to the work of Xiao-Qian [150] for up-to-date information on the development of microfluidic devices aimed at bacterial chemotaxis.

Pseudomonas aeruginosa PAO1 was studied for bacterial chemotaxis via a microfluidic approach by Jeong et al. [151]. The authors maintained a stable linear concentration gradient by diffusional mixing of laminar flow in a three-inlet microfluidic device. Peptone and trichloroethylene were studied as chemoeffectors. The microfluidic device clearly demonstrated that $P$. aeruginosa showed attraction towards peptone while repulsion towards trichloroethylene. It was further verified with a chemotactic mutant PC4 that showed non-chemotactic behavior. The authors concluded that microfluidic device facilitated the quantitative chemotaxis with a better understanding of the motility mechanism of $P$. aeruginosa.

In another study, Talaromyces helices were studied for benzo[a]pyrene $(\mathrm{BaP})$ bioremediation. The model fungus is reported to degrade PAHs, but to better understand the transport mechanism and uptake of hydrophobic pollutants, a microfluidic system was utilized [152]. The authors spiked the microfluidic chamber with $\mathrm{BaP}$ to mimic the polluted soil environment. The microfluidic system was cultured, and mycelium growth was observed through time-lapse epifluorescence microscopy. The authors confirmed the intracellular storage of $\mathrm{BaP}$ in vesicles after $24-h$ incubation. The study confirmed the potential application of the microfluidic system in bioremediation. In future, the study will help in identifying the biostimulation parameters that have improved the $\mathrm{BaP}$ mobilization in fungus.

Microfluidics has been extensively applied for environmental applications such as graphene-based microbots for toxic heavy metal recovery from wastewater streams [153], photocatalytic water treatment [154], and utilization in mini-metagenomics to identify novel microbial lineage in environmental samples [155]. However, literature is unable to furnish much data regarding the utilization of microfluidic systems for polycyclic aromatic compounds degradation by microorganisms.

\section{Bottlenecks and recent developments in chemotaxis-linked PAHs biodegradation}

The literature furnishes a plethora of information on chemotaxis. But, utilization of this important bacterial phenomenon for effective degradation of aromatic compounds is impeded by certain bottlenecks necessitating further investigation. Signal molecules recognition is the key obstacle in this phenomenon which is supported by following observations: (a) same compound/ligand recognition by different paralogous receptors; (b) mobility due to the presence of receptors parallel to chemoreceptors, i.e., energy taxis; (c) significant sequence divergence, even in sensor domains of the same family. In addition to these observations, functions of major bacterial sensor proteins are still unknown. Therefore, functional annotation of proteins in signal transduction research requires further research.

After the pioneering work of Adler on qualitative and quantitative bacterial chemotaxis (Fig. 2), several methods have been developed to determine chemotaxis, including microscope analysis, fluorescent labeling, and microfluidic devices due to the potential application of chemotaxis in clinical and environmental studies. However, these methods are laborious and time-consuming. In a recent study, Davidov et al. [156] presented a novel method to quantify bacterial chemotaxis within minutes of using silicon femtoliter-well arrays by optical measurement. In this method, silicon well acts as a diffraction grating in PRISM (phase-shift reflectometric interference spectroscopic measurements) that enables label-free, real-time quantification of bacterial cells in an optical readout. The application of this technique will immensely reduce the bacterial chemotaxis quantification time.

Since complete mineralization of PAHs is a combined effort of different microbial communities, biodegradation 


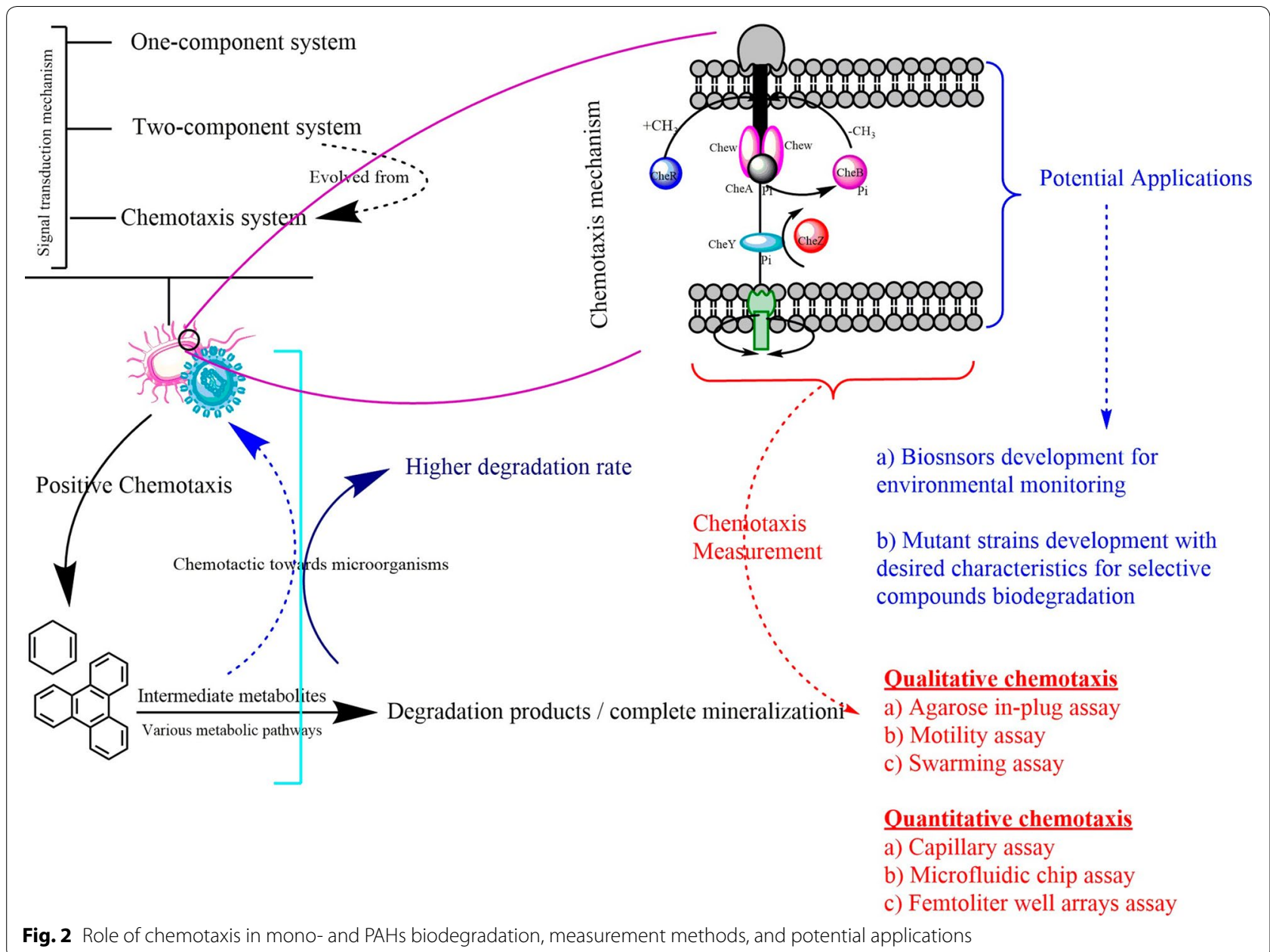

of PAHs resulted in several metabolites (intermediate products) that might be chemotactic to one community but repellent to others. The biosensing of ligands is a complex phenomenon. Therefore, in order to simplify the identification of chemoeffectors (ligands) by chemoreceptors, hybrid sensor proteins were constructed by fusing sensor domains and signaling domains of $P$. putida and E. coli, respectively [157]. Hybrid sensor proteins composed of PcaY, McfR, and NahY, which are receptors for aromatic acids, TCA intermediates, and naphthalene, have helped in identifying new ligands. Hybrid MCP development will revolutionize ligands detection based on high sensitivity and analysis simplicity, in addition to its application regardless of the MCP source.

\section{Conclusion and future perspectives}

Chemotaxis is the survival strategy of the microorganisms in response to environmental cues. This mechanism is exploited for the bioremediation of PAHs-contaminated soils. We have presented the molecular aspects of the chemotaxis mechanism. Complex signal transduction mechanisms lie on the foundation of the one-component system. The functional characterization of methylaccepting chemotaxis proteins is imperative to explore the underlying mechanism of ligand uptake and downstream signaling machinery. Limited information on the precise functional mechanism of chemotaxis is the key hindrance to benefitting from this phenomenon to its optimum potential. The complete underlying mechanism of chemotaxis is inevitable to engineer aromatic compound degrading novel strain.

There is a pressing need to conduct research using microfluidic devices for polycyclic aromatic compounds biodegradation. Modeling studies focusing on chemotaxis would help in identifying active hydrocarbondegrading strains. Future research should be focused on the potential integration of chemotaxis and degradation of priority pollutants. The development of genetically modified strains using specified promoters could help in identifying novel genes responsible for chemotaxis and their potential role in effective biodegradation. Much work is needed in developing novel degradation pathways 
for aromatic compound bioremediation and their potential link with microbial chemotaxis from unannotated microbial genomic data.

\begin{abstract}
Abbreviations
AC: Aromatic compounds; BaP: Benzo[a]pyrene; BTEX: Benzene, toluene, ethylbenzene, and xylene; CHASE: Cyclases/histidine kinases-associated sensory extracellular; DNA: Deoxyribonucleic acid; EPA: Environmental Protection Agency; EU: European Union; HAMP: Histidine kinase, adenylate cyclases, methyl-accepting proteins, phosphatases; HK: Histidine-kinase; HMW: Higher molecular weight; IUPAC: International Union of Pure and Applied Chemistry; LBD: Ligand binding domain; LMW: Low molecular weight; MCP: Methylaccepting chemotaxis protein; Mist: Microbial signaling transduction; ND: Not determined; PAHs: Polycyclic aromatic hydrocarbons; PAS: Per-Arnt-Sim; PPM: Parts per million; PRISM: Phase-shift reflectometric interference spectroscopic measurement; RT-PCR: Real-time polymerase chain reaction; TCA: Tricarboxylic acid.
\end{abstract}

\section{Acknowledgements}

Not applicable.

\section{Authors' contributions}

FA and DZ conceived the idea; FA wrote the manuscript; DZ and JS gave additional input and helped in finalizing the manuscript. All authors read and approved the final manuscript.

\section{Funding}

The review manuscript is derived from a project sponsored by the National Key R\&D Program of China (Grant No. 2018YFE0107100); and the National Natural Science Foundation of China (Grant No. 31772529); and the Priority Academic Program Development of Jiangsu Higher Education Institutions.

\section{Availability of data and materials}

Not applicable.

Ethics approval and consent to participate

Not applicable.

\section{Consent for publication}

Not applicable.

\section{Competing interests}

The authors declare that they have no competing interest.

Received: 15 January 2020 Accepted: 23 March 2020

Published online: 30 March 2020

\section{References}

1. Bi S, Sourjik V (2018) Stimulus sensing and signal processing in bacterial chemotaxis. Curr Opin Microbiol 45:22-29. https://doi.org/10.1016/j. mib.2018.02.002

2. Xin X, Othmer HG (2012) A "trimer of dimers"-based model for the chemotactic signal transduction network in bacterial chemotaxis. Bull Math Biol 74:2339-2382. https://doi.org/10.1007/s11538-012-9756-7

3. Xue C, Othmer HG (2009) Multiscale models of taxis-driven patterning in bacterial populations. SIAM J Appl Math 70:133-169. https://doi. org/10.1137/070711505

4. Blumer M, Blumer W, Reich T (1977) Polycyclic aromatic hydrocarbons in soils of a mountain valley: correlation with highway traffic and cancer incidence. Environ Sci Technol 11:1082-1084. https://doi.org/10.1021/ es60135a002

5. Nguyen TC, Loganathan P, Nguyen TV, Vigneswaran S, Kandasamy J, Slee D, Stevenson G, Naidu R (2014) Polycyclic aromatic hydrocarbons in road-deposited sediments, water sediments, and soils in Sydney, Australia: comparisons of concentration distribution, sources and potential toxicity. Ecotoxicol Environ Saf 104:339-348. https://doi. org/10.1016/j.ecoenv.2014.03.010

6. Li P, Wang Y, Li Y, Wai K, Li H, Tong L (2016) Gas-particle partitioning and precipitation scavenging of polycyclic aromatic hydrocarbons (PAHs) in the free troposphere in southern China. Atmos Environ 128:165-174. https://doi.org/10.1016/j.atmosenv.2015.12.030

7. Cerniglia CE (1992) Biodegradation of polycyclic aromatic hydrocarbons. Biodegradation 3:351-368. https://doi.org/10.1007/BF00129093

8. Haritash AK, Kaushik CP (2009) Biodegradation aspects of polycyclic aromatic hydrocarbons (PAHs): a review. J Hazard Mater 169:1-15. https ://doi.org/10.1016/.j.jhazmat.2009.03.137

9. CEC (Council of European Committees) (1999) Directive 1999/31/EC of the European Parliament and of the Council of 27 September 2001 of 26 April 1999 on the landfill of waste. Off J Eur Commun 182:107

10. Ghosal D, Ghosh S, Dutta TK, Ahn Y (2016) Current state of knowledge in microbial degradation of polycyclic aromatic hydrocarbons (PAHs): a review. Front Microbiol. https://doi.org/10.3389/fmicb.2016.01369

11. Fuchs G, Boll M, Heider J (2011) Microbial degradation of aromatic compounds-from one strategy to four. Nat Rev Microbiol 9:803-816. https://doi.org/10.1038/nrmicro2652

12. Ghosh S, Chisti Y, Banerjee UC (2012) Production of shikimic acid. Biotechnol Adv 30:1425-1431. https://doi.org/10.1016/j.biotechadv 2012.03.001

13. Zhan J (2009) Biosynthesis of Bacterial Aromatic Polyketides. http:// www.ingentaconnect.com/content/ben/ctmc/2009/00000009/00000 017/art00002. Accessed 6 Nov 2018

14. Zhu D, Zhang P, Xie C, Zhang W, Sun J, Qian W-J, Yang B (2017) Biodegradation of alkaline lignin by Bacillus ligniniphilus $L 1$. Biotechnol Biofuels 10:44. https://doi.org/10.1186/s13068-017-0735-y

15. Bhushan B, Halasz A, Thiboutot S, Ampleman G, Hawari J (2004) Chemotaxis-mediated biodegradation of cyclic nitramine explosives RDX, HMX, and CL-20 by Clostridium sp. EDB2. Biochem Biophys Res Commun 316:816-821. https://doi.org/10.1016/j.bbrc.2004.02.120

16. Marx RB, Aitken MD (2000) Bacterial chemotaxis enhances naphthalene degradation in a heterogeneous aqueous system. Environ Sci Technol 34:3379-3383. https://doi.org/10.1021/es000904k

17. Abdel-Shafy HI, Mansour MSM (2016) A review on polycyclic aromatic hydrocarbons: source, environmental impact, effect on human health and remediation. Egypt J Pet 25:107-123. https://doi.org/10.1016/j. ejpe.2015.03.011

18. Johnsen AR, Wick LY, Harms H (2005) Principles of microbial PAH-degradation in soil. Environ Pollut 133:71-84. https://doi.org/10.1016/j.envpo I.2004.04.015

19. Estrellan $C R$, lino $F(2010)$ Toxic emissions from open burning. Chemosphere 80:193-207. https://doi.org/10.1016/j.chemosphere.2010.03.057

20. Lima ALC, Farrington JW, Reddy CM (2005) Combustion-derived polycyclic aromatic hydrocarbons in the environment-a review. Environ Forensics 6:109-131. https://doi.org/10.1080/15275920590952739

21. Grimmer G, Hildebrandt A (1965) Kohlenwasserstoffe in der Umgebung des Menschen. Z Krebs-forsch 67:272-277. https://doi.org/10.1007/ BF00524860

22. Zhang J, Yang J, Wang R, Hou H, Du X, Fan S, Liu J, Dai J (2013) Effects of pollution sources and soil properties on distribution of polycyclic aromatic hydrocarbons and risk assessment. Sci Total Environ 463-464:110. https://doi.org/10.1016/j.scitotenv.2013.05.066

23. Bourotte C, Forti MC, Lucas Y, Melfi AJ (2009) Comparison of Polycyclic Aromatic Hydrocarbon (PAHs) concentrations in urban and natural forest soils in the Atlantic Forest (São Paulo State). An Acad Bras Cienc 81:127-136. https://doi.org/10.1590/S0001-37652009000100013

24. Pokhrel B, Gong P, Wang X, Wang C, Gao S (2018) Polycyclic aromatic hydrocarbons in the urban atmosphere of Nepal: distribution, sources, seasonal trends, and cancer risk. Sci Total Environ 618:1583-1590. https ://doi.org/10.1016/j.scitotenv.2017.09.329

25. Mishra N, Ayoko GA, Morawska L (2016) Atmospheric polycyclic aromatic hydrocarbons in the urban environment: occurrence, toxicity and source apportionment. Environ Pollut 208:110-117. https://doi. org/10.1016/j.envpol.2015.08.015

26. Wang C, Zhou S, Song J, Wu S (2018) Human health risks of polycyclic aromatic hydrocarbons in the urban soils of Nanjing, China. Sci Total Environ 612:750-757. https://doi.org/10.1016/j.scitotenv.2017.08.269 
27. Wu M-T, Lin P-C, Pan C-H, Peng C-Y (2019) Risk assessment of personal exposure to polycyclic aromatic hydrocarbons and aldehydes in three commercial cooking workplaces. Sci Rep 9:1661. https://doi. org/10.1038/s41598-018-38082-5

28. Leigh MB, Prouzová P, Macková M, Macek T, Nagle DP, Fletcher JS (2006) Polychlorinated biphenyl (PCB)-degrading bacteria associated with trees in a PCB-contaminated site. Appl Environ Microbiol 72:2331-2342. https://doi.org/10.1128/AEM.72.4.2331-2342.2006

29. Mangwani N, Kumari S, Das S (2017) Marine bacterial biofilms in bioremediation of polycyclic aromatic hydrocarbons (PAHs) under terrestrial condition in a soil microcosm. Pedosphere 27:548-558. https://doi. org/10.1016/S1002-0160(17)60350-3

30. Turnbull GA, Morgan JAW, Whipps JM, Saunders JR (2001) The role of motility in the in vitro attachment of Pseudomonas putida PaW8 to wheat roots. FEMS Microbiol Ecol 35:57-65. https://doi.org/10.1016/ S0168-6496(00)00111-2

31. Samanta SK, Bhushan B, Chauhan A, Jain RK (2000) Chemotaxis of a Ralstonia sp. SJ98 toward different nitroaromatic compounds and their degradation. Biochem Biophys Res Commun 269:117-123. https://doi. org/10.1006/bbrc.2000.2204

32. Simon MI (1995) Signal Transduction in Microorganisms. In: Joint I (ed) Molecular ecology of aquatic microbes. Springer, Berlin Heidelberg, pp 205-215

33. Ramos JL, Duque E, Gallegos M-T, Godoy P, Ramos-González MI, Rojas A, Terán W, Segura A (2002) Mechanisms of solvent tolerance in gram-negative bacteria. Annu Rev Microbiol 56:743-768. https://doi. org/10.1146/annurev.micro.56.012302.161038

34. Parales RE, Parales JV, Pelletier DA, Ditty JL (2008) Chapter 1 diversity of microbial toluene degradation pathways. Advances in applied microbiology. Academic Press, New York, pp 1-73

35. Wuichet K, Zhulin IB (2010) Origins and diversification of a complex signal transduction system in prokaryotes. Sci Signal 3:ra50. https://doi. org/10.1126/scisignal.2000724

36. Lacal J, Reyes-Darias JA, García-Fontana C, Ramos J-L, Krell T (2013) Tactic responses to pollutants and their potential to increase biodegradation efficiency. J Appl Microbiol 114:923-933. https://doi.org/10.1111/ jam. 12076

37. Ulrich LE, Koonin EV, Zhulin IB (2005) One-component systems dominate signal transduction in prokaryotes. Trends Microbiol 13:52-56. https://doi.org/10.1016/j.tim.2004.12.006

38. Alekshun MN, Levy SB, Mealy TR, Seaton BA, Head JF (2001) The crystal structure of MarR, a regulator of multiple antibiotic resistance, at $2.3 \mathrm{~A}$ resolution. Nat Struct Biol 8:710-714. https://doi.org/10.1038/90429

39. Tuckerman JR, Gonzalez G, Sousa EHS, Wan X, Saito JA, Alam M, GillesGonzalez M-A (2009) An oxygen-sensing diguanylate cyclase and phosphodiesterase couple for c-di-GMP control. Biochemistry 48:9764-9774. https://doi.org/10.1021/bi901409g

40. Krell T (2016) Two-component systems that control the expression of aromatic hydrocarbon degradation pathways. Stress and environmental regulation of gene expression and adaptation in bacteria. Wiley, New York, pp 247-256

41. Nixon BT, Ronson CW, Ausubel FM (1986) Two-component regulatory systems responsive to environmental stimuli share strongly conserved domains with the nitrogen assimilation regulatory genes $n+r B$ and $n t r C$. PNAS 83:7850-7854. https://doi.org/10.1073/pnas.83.20.7850

42. Galperin MY (2010) Diversity of structure and function of response regulator output domains. Curr Opin Microbiol 13:150-159. https://doi. org/10.1016/j.mib.2010.01.005

43. Stock AM, Robinson VL, Goudreau PN (2000) Two-component signal transduction. Annu Rev Biochem 69:183-215. https://doi.org/10.1146/ annurev.biochem.69.1.183

44. Capra EJ, Laub MT (2012) Evolution of two-component signal transduction systems. Annu Rev Microbiol 66:325-347. https://doi.org/10.1146/ annurev-micro-092611-150039

45. Zschiedrich CP, Keidel V, Szurmant H (2016) Molecular mechanisms of two-component signal transduction. J Mol Biol 428:3752-3775. https:// doi.org/10.1016/j.jmb.2016.08.003

46. Lacal J, Alfonso C, Liu X, Parales RE, Morel B, Conejero-Lara F, Rivas G, Duque E, Ramos JL, Krell T (2010) Identification of a chemoreceptor for tricarboxylic acid cycle intermediates differential chemotactic response towards receptor ligands. J Biol Chem 285:23126-23136. https://doi. org/10.1074/jbc.M110.110403

47. Österberg S, Skärfstad E, ShinglerV (2010) The $\sigma$-factor FliA, ppGpp and DksA coordinate transcriptional control of the aer2 gene of Pseudomonas putida. Environ Microbiol 12:1439-1451. https://doi.org/10.11 11/j.1462-2920.2009.02139.x

48. Partridge JD, Nhu NTQ, Dufour YS, Harshey RM (2019) Escherichia coli remodels the chemotaxis pathway for swarming. mBio 10:e00316e00319. https://doi.org/10.1128/mBio.00316-19

49. Hansen $\mathrm{CH}$, Endres RG, Wingreen NS (2008) Chemotaxis in Escherichia coli: a molecular model for robust precise adaptation. PLoS Comput Biol 4:e1-e1. https://doi.org/10.1371/journal.pcbi.0040001

50. Parkinson JS, Hazelbauer GL, Falke JJ (2015) Signaling and sensory adaptation in Escherichia coli chemoreceptors: 2015 update. Trends Microbiol 23:257-266. https://doi.org/10.1016/j.tim.2015.03.003

51. Lacal J, García-Fontana C, Muñoz-Martínez F, Ramos J-L, Krell T (2010) Sensing of environmental signals: classification of chemoreceptors according to the size of their ligand binding regions. Environ Microbiol 12:2873-2884. https://doi.org/10.1111/j.1462-2920.2010.02325.x

52. Matsunaga T, Okamura Y, Fukuda Y, Wahyudi AT, Murase $Y$, Takeyama $H$ (2005) Complete genome sequence of the facultative anaerobic magnetotactic bacterium Magnetospirillum sp. strain AMB-1. DNA Res 12:157-166. https://doi.org/10.1093/dnares/dsi002

53. Ortega Á, Zhulin IB, Krell T (2017) Sensory repertoire of bacterial chemoreceptors. Microbiol Mol Biol Rev 81:e00033-e00117. https:// doi.org/10.1128/MMBR.00033-17

54. Hazelbauer GL, Lai W-C (2010) Bacterial chemoreceptors: providing enhanced features to two-component signaling. Curr Opin Microbiol 13:124-132. https://doi.org/10.1016/j.mib.2009.12.014

55. Hazelbauer GL, Falke JJ, Parkinson JS (2008) Bacterial chemoreceptors: high-performance signaling in networked arrays. Trends Biochem Sci 33:9-19. https://doi.org/10.1016/j.tibs.2007.09.014

56. Wadhams GH, Armitage JP (2004) Making sense of it all: bacterial chemotaxis. Nat Rev Mol Cell Biol 5:1024-1037. https://doi. org/10.1038/nrm 1524

57. Berg HC, Purcell EM (1977) Physics of chemoreception. Biophys J 20:193-219

58. Tena-Garitaonaindia M, Llamas I, Toral L, Sampedro I (2019) Chemotaxis of halophilic bacterium Halomonas anticariensis FP35 towards the environmental pollutants phenol and naphthalene. Sci Total Environ 669:631-636. https://doi.org/10.1016/j.scitotenv.2019.02.444

59. Sourjik V, Wingreen NS (2012) Responding to chemical gradients: bacterial chemotaxis. Curr Opin Cell Biol 24:262-268. https://doi. org/10.1016/j.ceb.2011.11.008

60. Yonekawa H, Hayashi H, Parkinson JS (1983) Requirement of the cheB function for sensory adaptation in Escherichia coli. J Bacteriol 156:1228-1235

61. Wuichet K, Alexander RP, Zhulin IB (2007) Comparative genomic and protein sequence analyses of a complex system controlling bacterial chemotaxis. Meth Enzymol 422:1-31. https://doi.org/10.1016/50076 $-6879(06) 22001-9$

62. Alexander RP, Zhulin IB (2007) Evolutionary genomics reveals conserved structural determinants of signaling and adaptation in microbial chemoreceptors. Proc Natl Acad Sci 104:2885. https://doi. org/10.1073/pnas.0609359104

63. Ferris HU, Dunin-Horkawicz S, Hornig N, Hulko M, Martin J, Schultz JE, Zeth K, Lupas AN, Coles M (2012) Mechanism of regulation of receptor histidine kinases. Structure 20:56-66. https://doi.org/10.1016/j. str.2011.11.014

64. Wuichet K, Alexander RP, Zhulin IB (2007) Comparative genomic and protein sequence analyses of a complex system controlling bacterial chemotaxis. In: Simon MI, Crane BR, Crane A (eds) Methods in enzymology. Academic Press, New York, pp 3-31

65. Ulrich LE, Zhulin IB (2010) The MiST2 database: a comprehensive genomics resource on microbial signal transduction. Nucleic Acids Res 38:D401-D407. https://doi.org/10.1093/nar/gkp940

66. Rao CV, Ordal GW (2009) The molecular basis of excitation and adaptation during chemotactic sensory transduction in bacteria. Contributions to microbiology. Karger Publishers, Basel, pp 33-64

67. Stock JB, Clarke S, Koshland DE (1984) The protein carboxylmethyltransferase involved in Escherichia coli and Salmonella typhimurium 
chemotaxis. Methods in Enzymology. Academic Press, New York, pp 310-321

68. Lupas A, Stock J (1989) Phosphorylation of an N-terminal regulatory domain activates the CheB methylesterase in bacterial chemotaxis. J Biol Chem 264:17337-17342

69. Szurmant H, Ordal GW (2004) Diversity in chemotaxis mechanisms among the bacteria and archaea. Microbiol Mol Biol Rev 68:301-319. https://doi.org/10.1128/MMBR.68.2.301-319.2004

70. Wang Y-H, Huang Z, Liu S-J (2019) Chemotaxis towards aromatic compounds: insights from Comamonas testosteroni. Int J Mol Sci 20:2701. https://doi.org/10.3390/ijms20112701

71. Harwood CS, Rivelli M, Ornston LN (1984) Aromatic acids are chemoattractants for Pseudomonas putida. J Bacteriol 160:622-628

72. Parales RE, Luu RA, Hughes JG, Ditty JL (2015) Bacterial chemotaxis to xenobiotic chemicals and naturally-occurring analogs. Curr Opin Biotechnol 33:318-326. https://doi.org/10.1016/j.copbio.2015.03.017

73. Sampedro I, Parales RE, Krell T, Hill JE (2015) Pseudomonas chemotaxis. FEMS Microbiol Rev 39:17-46. https://doi.org/10.1111/1574-6976.12081

74. Harwood CS, Parales RE, Dispensa M (1990) Chemotaxis of Pseudomonas putida toward chlorinated benzoates. Appl Environ Microbiol 56:1501-1503

75. Parales RE, Ditty JL, Harwood CS (2000) Toluene-degrading bacteria are chemotactic towards the environmental pollutants benzene, toluene, and trichloroethylene. Appl Environ Microbiol 66:4098-4104

76. Huang Z, Ni B, Jiang CY, Wu YF, He YZ, Parales RE, Liu SJ (2016) Direct sensing and signal transduction during bacterial chemotaxis toward aromatic compounds in Comamonas testosteroni. Mol Microbiol 101:224-237. https://doi.org/10.1111/mmi.13385

77. Marín M, Pérez-Pantoja D, Donoso R, Wray V, González B, Pieper DH (2010) Modified 3-oxoadipate pathway for the biodegradation of methylaromatics in Pseudomonas reinekei MT1. J Bacteriol 192:15431552. https://doi.org/10.1128/JB.01208-09

78. Suvorova IA, Gelfand MS (2019) Comparative genomic analysis of the regulation of aromatic metabolism in betaproteobacteria. Front Microbiol. https://doi.org/10.3389/fmicb.2019.00642

79. Spormann AM, Widdel F (2000) Metabolism of alkylbenzenes, alkanes, and other hydrocarbons in anaerobic bacteria. Biodegradation 11:85-105. https://doi.org/10.1023/A:1011122631799

80. Chakraborty R, Coates JD (2004) Anaerobic degradation of monoaromatic hydrocarbons. Appl Microbiol Biotechnol 64:437-446. https://doi. org/10.1007/s00253-003-1526-x

81. Foght J (2008) Anaerobic biodegradation of aromatic hydrocarbons: pathways and prospects. MMB 15:93-120. https://doi. org/10.1159/000121324

82. Weelink SAB, van Eekert MHA, Stams AJM (2010) Degradation of BTEX by anaerobic bacteria: physiology and application. Rev Environ Sci Biotechnol 9:359-385. https://doi.org/10.1007/s11157-010-9219-2

83. Vandecasteele J-P, Jones T (2008) Biodegradation of monoaromatic and chloroaromatic hydrocarbons. Petroleum microbiology. IFP Publications, France, pp 241-328

84. Santos PM, Benndorf D, Sá-Correia I (2004) Insights into Pseudomonas putida KT2440 response to phenol-induced stress by quantitative proteomics. Proteomics 4:2640-2652. https://doi.org/10.1002/pmic.20030 0793

85. Nogales J, García JL, Díaz E (2017) Degradation of aromatic compounds in Pseudomonas: a systems biology view. In: Rojo F (ed) Aerobic utilization of hydrocarbons, oils and lipids. Springer, Cham, pp 1-49

86. Molina L, Duque E, Gómez MJ, Krell T, Lacal J, García-Puente A, García V, Matilla MA, Ramos J-L, Segura A (2011) The pGRT1 plasmid of Pseudomonas putida DOT-T1E encodes functions relevant for survival under harsh conditions in the environment. Environ Microbiol 13:2315-2327. https://doi.org/10.1111/j.1462-2920.2011.02492.x

87. Luu RA, Kootstra JD, Nesteryuk V, Brunton CN, Parales JV, Ditty JL, Parales RE (2015) Integration of chemotaxis, transport and catabolism in Pseudomonas putida and identification of the aromatic acid chemoreceptor PcaY: chemotaxis to aromatic acids in Pseudomonas putida. Mol Microbiol 96:134-147. https://doi.org/10.1111/mmi.12929

88. Zhang J, Xin Y, Liu H, Wang S, Zhou N (2008) Metabolism-independent chemotaxis of Pseudomonas sp. strain WBC-3 toward aromatic compounds. J Envriron Sci 20:1238-1242. https://doi.org/10.1016/S1001 $-0742(08) 62215-9$
89. Pandey J, Sharma NK, Khan F, Ghosh A, Oakeshott JG, Jain RK, Pandey G (2012) Chemotaxis of Burkholderia sp. Strain SJ98 towards chloronitroaromatic compounds that it can metabolise. BMC Microbiol 12:19. https://doi.org/10.1186/1471-2180-12-19

90. Min J, Wang B, Hu X (2017) Effect of inoculation of Burkholderia sp. strain SJ98 on bacterial community dynamics and para -nitrophenol, 3-methyl-4-nitrophenol, and 2-chloro-4-nitrophenol degradation in soil. Sci Rep 7:1-9. https://doi.org/10.1038/s41598-017-06436-0

91. Liu X, Parales RE (2009) Bacterial chemotaxis to atrazine and related s-triazines. Appl Environ Microbiol 75:5481-5488. https://doi. org/10.1128/AEM.01030-09

92. Iwaki H, Muraki T, Ishihara S, Hasegawa Y, Rankin KN, Sulea T, Boyd J, Lau PCK (2007) Characterization of a pseudomonad 2-nitrobenzoate nitroreductase and its catabolic pathway-associated 2-hydroxylaminobenzoate mutase and a chemoreceptor involved in 2-nitrobenzoate chemotaxis. J Bacteriol 189:3502-3514. https://doi.org/10.1128/ JB.01098-06

93. Grimm AC, Harwood CS (1999) NahY, a catabolic plasmid-encoded receptor required for chemotaxis of Pseudomonas putida to the aromatic hydrocarbon naphthalene. J Bacteriol 181:3310-3316

94. Gordillo F, Chávez FP, Jerez CA (2007) Motility and chemotaxis of Pseudomonas sp. B4 towards polychlorobiphenyls and chlorobenzoates. FEMS Microbiol Ecol 60:322-328. https://doi.org/10.111 1/j.1574-6941.2007.00293.x

95. Wu G, Feng Y, Boyd SA (2003) Characterization of bacteria capable of degrading soil-sorbed biphenyl. Bull Environ Contam Toxicol 71:768-775. https://doi.org/10.1007/s00128-003-0198-7

96. Furukawa K, Miyazaki T (1986) Cloning of a gene cluster encoding biphenyl and chlorobiphenyl degradation in Pseudomonas pseudoalcaligenes. J Bacteriol 166:392-398

97. Vangnai AS, Takeuchi K, Oku S, Kataoka N, Nitisakulkan T, Tajima T, Kato J (2013) Identification of CtpL as a chromosomally encoded chemoreceptor for 4-chloroaniline and catechol in Pseudomonas aeruginosa PAO1. Appl Environ Microbiol 79:7241-7248. https://doi.org/10.1128/ AEM.02428-13

98. Wu Y, Zaiden N, Cao B (2018) The core- and pan-genomic analyses of the genus Comamonas: from environmental adaptation to potential virulence. Front Microbiol. https://doi.org/10.3389/fmicb.2018.03096

99. Andreoni V , Gianfreda L (2007) Bioremediation and monitoring of aromatic-polluted habitats. Appl Microbiol Biotechnol 76:287-308. https://doi.org/10.1007/s00253-007-1018-5

100. Huang Z, Wang Y-H, Zhu H-Z, Andrianova EP, Jiang C-Y, Li D, Ma L, Feng J, Liu Z-P, Xiang H, Zhulin IB, Liu S-J (2019) Cross talk between chemosensory pathways that modulate chemotaxis and biofilm formation. mBio 10:e02876-e02918. https://doi.org/10.1128/mBio.02876-18

101. Tang Q, Lu T, Liu S-J (2018) Developing a synthetic biology toolkit for Comamonas testosteroni, an emerging cellular chassis for bioremediation. ACS Synth Biol 7:1753-1762. https://doi.org/10.1021/acssy nbio.7b00430

102. Vítková M, Dercová K, Molnárová J, Tóthová L, Polek B, Godočíková J (2011) The effect of lignite and comamonas testosteroni on pentachlorophenol biodegradation and soil ecotoxicity. Water Air Soil Pollut 218:145-155. https://doi.org/10.1007/s11270-010-0630-7

103. Di Martino C, López NI, Raiger lustman LJ (2012) Isolation and characterization of benzene, toluene and xylene degrading Pseudomonas sp. selected as candidates for bioremediation. Int Biodeterior Biodegrad 67:15-20. https://doi.org/10.1016/j.ibiod.2011.11.004

104. Hendrickx B, Junca H, Vosahlova J, Lindner A, Rüegg I, Bucheli-Witschel M, Faber F, Egli T, Mau M, Schlömann M, Brennerova M, Vl Brenner, Pieper DH, Top EM, Dejonghe W, Bastiaens L, Springael D (2006) Alternative primer sets for PCR detection of genotypes involved in bacterial aerobic BTEX degradation: distribution of the genes in BTEX degrading isolates and in subsurface soils of a BTEX contaminated industrial site. J Microbiol Methods 64:250-265. https://doi.org/10.1016/j.mimet .2005 .04 .018

105. Lee EY, Hong SH, Oh MH, Lim JS (2011) Characterization biodegradation of benzene, toluene, ethylbenzene, and xylenes by the newly isolated bacterium Pseudomonas putida AY-10 in rhizosphere of wastewater treatment reed. IACSIT Press, Singapore

106. Koutinas M, Lam M-C, Kiparissides A, Silva-Rocha R, Godinho M, Livingston AG, Pistikopoulos EN, de Lorenzo V, Dos Santos VAPM, Mantalaris A 
(2010) The regulatory logic of $m$-xylene biodegradation by Pseudomonas putida $\mathrm{mt}-2$ exposed by dynamic modelling of the principal node Ps/Pr of the TOL plasmid. Environ Microbiol 12:1705-1718. https ://doi.org/10.1111/j.1462-2920.2010.02245.x

107. Otenio MH, da Silva MTL, Marques MLO, Roseiro JC, Bidoia ED (2005) Benzene, toluene and xylene biodegradation by Pseudomonas putida CCMI 852. Braz J Microbiol 36:258-261. https://doi.org/10.1590/S1517 $-83822005000300010$

108. Arenghi FLG, Barbieri P, Bertoni G, de Lorenzo V (2001) New insights into the activation of o-xylene biodegradation in Pseudomonas stutzeri OX 1 by pathway substrates. EMBO Rep 2:409-414. https://doi.org/10.1093/ embo-reports/kve092

109. Dobslaw D, Engesser K-H (2015) Degradation of toluene by ortho cleavage enzymes in Burkholderia fungorum FLU100. Microb Biotechnol 8:143-154. https://doi.org/10.1111/1751-7915.12147

110. Millacura FA, Cárdenas F, Mendez V, Seeger M, Rojas LA (2017) Degradation of benzene by the heavy-metal resistant bacterium Cupriavidus metallidurans $\mathrm{CH} 34$ reveals its catabolic potential for aromatic compounds. bioRxiv. https://doi.org/10.1101/164517

111. Qu D, Zhao Y, Sun J, Ren H, Zhou R (2015) BTEX biodegradation and its nitrogen removal potential by a newly isolated Pseudomonas thivervalensis MAH1. Can J Microbiol 61:691-699. https://doi.org/10.1139/ cjm-2015-0152

112. Nichols NN, Lunde TA, Graden KC, Hallock KA, Kowalchyk CK, Southern RM, Soskin EJ, Ditty JL (2012) Chemotaxis to furan compounds by furan-degrading pseudomonas strains. Appl Environ Microbiol 78:6365-6368. https://doi.org/10.1128/AEM.01104-12

113. Parales RE (2004) Nitrobenzoates and aminobenzoates are chemoattractants for Pseudomonas strains. Appl Environ Microbiol 70:285-292. https://doi.org/10.1128/AEM.70.1.285-292.2004

114. Rabinovitch-Deere CA, Parales RE (2012) Three types of taxis used in the response of Acidovorax sp. strain JS42 to 2-nitrotoluene. Appl Environ Microbiol 78:2306-2315. https://doi.org/10.1128/AEM.07183-11

115. Arora PK, Bae H (2014) Biotransformation and chemotaxis of 4-chloro2-nitrophenol by Pseudomonas sp. JHN. Microb Cell Fact. https://doi. org/10.1186/s12934-014-0110-7

116. Arora PK, Srivastava A, Singh VP (2014) Degradation of 4-chloro-3-nitrophenol via a novel intermediate, 4-chlororesorcinol by Pseudomonas sp. JHN. Sci Rep 4:4475. https://doi.org/10.1038/srep04475

117. Tremaroli V, Vacchi Suzzi C, Fedi S, Ceri H, Zannoni D, Turner RJ (2010) Tolerance of Pseudomonas pseudoalcaligenes KF707 to metals, polychlorobiphenyls and chlorobenzoates: effects on chemotaxis-, biofilmand planktonic-grown cells. FEMS Microbiol Ecol 74:291-301. https:// doi.org/10.1111/j.1574-6941.2010.00965.x

118. Grimm AC, Harwood CS (1997) Chemotaxis of Pseudomonas spp. to the polyaromatic hydrocarbon naphthalene. Appl Environ Microbiol 63:4111-4115

119. Samanta SK, Jain RK (2000) Evidence for plasmid-mediated chemotaxis of Pseudomonas putida towards naphthalene and salicylate. Can J Microbiol 46:1-6. https://doi.org/10.1139/cjm-46-1-1

120. Ortega-Calvo JJ, Marchenko Al, Vorobyov AV, Borovick RV (2003) Chemotaxis in polycyclic aromatic hydrocarbon-degrading bacteria isolated from coal-tar- and oil-polluted rhizospheres. FEMS Microbiol Ecol 44:373-381. https://doi.org/10.1016/S0168-6496(03)00092-8

121. Bisht S, Pandey P, Sood A, Sharma S, Bisht NS (2010) Biodegradation of naphthalene and anthracene by chemo-tactically active rhizobacteria of populus deltoides. Braz J Microbiol 41:922-930. https://doi. org/10.1590/S1517-83822010000400011

122. Gasperotti AF, Revuelta MV, Studdert CA, Herrera Seitz MK (2018) Identification of two different chemosensory pathways in representatives of the genus Halomonas. BMC Genomics 19:266. https://doi.org/10.1186/ s12864-018-4655-4

123. Corti Monzón G, Nisenbaum M, Herrera Seitz MK, Murialdo SE (2018) New findings on aromatic compounds' degradation and their metabolic pathways, the biosurfactant production and motility of the halophilic bacterium Halomonas sp. KHS3. Curr Microbiol 75:1108-1118. https://doi.org/10.1007/s00284-018-1497-x

124. Ehrenhauser FS (2015) PAH and IUPAC nomenclature. Polycyclic Aromat Compd 35:161-176. https://doi.org/10.1080/10406638.2014.918551
125. Fletcher JH, Dermer OC, Fox RB (1974) Polycyclic aromatic hydrocarbons. Nomenclature of organic compounds. American Chemical Society, Washington, pp 29-42

126. The National Academies (1983) Polycyclic aromatic hydrocarbons: evaluation of sources and effects. The National Academies Press, Washington

127. Shrestha RA, Pham TD, Sillanpää M (2010) Electro ultrasonic remediation of polycyclic aromatic hydrocarbons from contaminated soil. J Appl Electrochem 40:1407-1413. https://doi.org/10.1007/s1080 0-010-0117-7

128. Gai C, Dong Y, Yang S, Zhang Z, Liang J, Li J (2016) Thermal decomposition kinetics of light polycyclic aromatic hydrocarbons as surrogate biomass tar. RSC Adv 6:83154-83162. https://doi.org/10.1039/C6RA1 $5513 \mathrm{H}$

129. Melnyk A, Dettlaff A, Kuklińska K, Namieśnik J, Wolska L (2015) Concentration and sources of polycyclic aromatic hydrocarbons (PAHs) and polychlorinated biphenyls (PCBs) in surface soil near a municipal solid waste (MSW) landfill. Sci Total Environ 530-531:18-27. https://doi. org/10.1016/j.scitotenv.2015.05.092

130. Rao KJ, Ghosh Chaudhuri R, Paria S (2014) Naphthalene degradation in the presence of natural-synthetic surfactants mixture by mixed bacterial cultures. J Environ Chem Eng 2:826-831. https://doi.org/10.1016/j. jece.2014.02.011

131. Sylian Rodriguez, Bishop Paul L (2008) Enhancing the biodegradation of polycyclic aromatic hydrocarbons: effects of nonionic surfactant addition on biofilm function and structure. J Environ Eng 134:505-512. https://doi.org/10.1061/(ASCE)0733-9372(2008)134:7(505)

132. Li J, Luo C, Song M, Dai Q, Jiang L, Zhang D, Zhang G (2017) Biodegradation of phenanthrene in polycyclic aromatic hydrocarbon-contaminated wastewater revealed by coupling cultivation-dependent and -independent approaches. Environ Sci Technol 51:3391-3401. https:// doi.org/10.1021/acs.est.6b04366

133. Gran-Scheuch A, Fuentes E, Bravo DM, Jiménez JC, Pérez-Donoso JM (2017) Isolation and characterization of phenanthrene degrading bacteria from diesel fuel-contaminated antarctic soils. Front Microbiol. https://doi.org/10.3389/fmicb.2017.01634

134. Lawal AT (2017) Polycyclic aromatic hydrocarbons. A review. Cogent Environ Sci 3:1339841. https://doi.org/10.1080/23311843.2017.1339841

135. Barathi S, Vasudevan N (2001) Utilization of petroleum hydrocarbons by Pseudomonas fluorescens isolated from a petroleum-contaminated soil. Environ Int 26:413-416. https://doi.org/10.1016/50160 $-4120(01) 00021-6$

136. Kanaly RA, Harayama S (2000) Biodegradation of high-molecularweight polycyclic aromatic hydrocarbons by bacteria. J Bacteriol 182:2059-2067. https://doi.org/10.1128/JB.182.8.2059-2067.2000

137. Dutta K, Shityakov S, Khalifa I, Ballav S, Jana D, Manna T, Karmakar M, Raul P, Guchhait KC, Ghosh C (2019) Enhanced biodegradation of naphthalene by Pseudomonas sp. consortium immobilized in calcium alginate beads. bioRxiv. https://doi.org/10.1101/631135

138. Gao S, Seo J-S, Wang J, Keum Y-S, Li J, Li QX (2013) Multiple degradation pathways of phenanthrene by Stenotrophomonas maltophilia C6. Int Biodeterior Biodegrad 79:98-104. https://doi.org/10.1016/j.ibiod .2013 .01 .012

139. Nayak AS, Sanjeev Kumar S, Santosh Kumar M, Anjaneya O, Karegoudar TB (2011) A catabolic pathway for the degradation of chrysene by Pseudoxanthomonas sp. PNK-04. FEMS Microbiol Lett 320:128-134. https:// doi.org/10.1111/j.1574-6968.2011.02301.x

140. Xu J, Wu X, Wang H, Dekang K, Liu Z (2018) Metabolic pathways of polycyclic aromatic hydrocarbons and functional regulation of proteins. Mini-Rev Org Chem 15:76-83. https://doi.org/10.2174/1570193X14 666170721150147

141. Pedit JA, Marx RB, Miller CT, Aitken MD (2002) Quantitative analysis of experiments on bacterial chemotaxis to naphthalene. Biotechol Bioeng 78:626-634. https://doi.org/10.1002/bit.10244

142. Law AMJ, Aitken MD (2003) Bacterial chemotaxis to naphthalene desorbing from a nonaqueous liquid. Appl Environ Microbiol 69:59685973. https://doi.org/10.1128/aem.69.10.5968-5973.2003

143. Hanzel J, Harms H, Wick LY (2010) Bacterial chemotaxis along vaporphase gradients of naphthalene. Environ Sci Technol 44:9304-9310. https://doi.org/10.1021/es100776h 
144. Malloggi F (2016) Microfluidics: from basic principles to applications. In: Lang P, Liu Y (eds) Soft matter at aqueous interfaces. Springer International Publishing, Cham, pp 515-546

145. Mao H, Cremer PS, Manson MD (2003) A sensitive, versatile microfluidic assay for bacterial chemotaxis. Proc Natl Acad Sci USA 100:5449-5454. https://doi.org/10.1073/pnas.0931258100

146. Lanning LM, Ford RM, Long T (2008) Bacterial chemotaxis transverse to axial flow in a microfluidic channel. Biotechnol Bioeng 100:653-663. https://doi.org/10.1002/bit.21814

147. Long T, Ford RM (2009) Enhanced transverse migration of bacteria by chemotaxis in a porous T-sensor. Environ Sci Technol 43:1546-1552. https://doi.org/10.1021/es802558j

148. Stocker R, Seymour JR, Samadani A, Hunt DE, Polz MF (2008) Rapid chemotactic response enables marine bacteria to exploit ephemeral microscale nutrient patches. PNAS 105:4209-4214. https://doi. org/10.1073/pnas.0709765105

149. Lin B, Qin J (2008) Laboratory on a microfluidic chip. Science Press, Beijing

150. Zang X-Q, Li Z-Y, Zhang X-Y, Jiang L, Ren N-Q, Sun K (2017) Advance in bacteria chemotaxis on microfluidic devices. Chin J Anal Chem 45:1734-1744. https://doi.org/10.1016/S1872-2040(17)61050-8

151. Jeong H-H, Lee S-H, Kim J-M, Kim H-E, Kim Y-G, Yoo JY, Chang W-S, Lee C-S (2010) Microfluidic monitoring of Pseudomonas aeruginosa chemotaxis under the continuous chemical gradient. Biosens Bioelectron 26:351-356. https://doi.org/10.1016/j.bios.2010.08.006

152. Baranger C, Creusot L, Sun X, Pezron I, Goff AL, Fayeulle A (2018) Microfluidic approaches for improved bioremediation: monitoring pollutant uptake in a soil fungus. In: Proceedings of the 4th World Congress on New Technologies (NewTech'18). Madrid, Spain. https:// doi.org/10.11159/icepr18.184.
153. Vilela D, Parmar J, Zeng Y, Zhao Y, Sánchez S (2016) Graphene-based microbots for toxic heavy metal removal and recovery from water. Nano Lett 16:2860-2866. https://doi.org/10.1021/acs.nanolett.6b00768

154. Yew M, Ren Y, Koh KS, Sun C, Snape C (2018) A review of state-of-the-art microfluidic technologies for environmental applications: detection and remediation. Glob Chall. https://doi.org/10.1002/gch2.201800060

155. Yu FB, Blainey PC, Schulz F, Woyke T, Horowitz MA, Quake SR (2017) Microfluidic-based mini-metagenomics enables discovery of novel microbial lineages from complex environmental samples. bioRxiv. https ://doi.org/10.1101/114496

156. Davidov T, Granik N, Zahran S, Leonard H, Adir I, Elul O, Fried T, Gil A, Mayo B, Ohayon S, Sarig S, Shasha N, Tsedef S, Weiner S, BrunwasserMeirom M, Ereskovsky A, Katz N, Kaufmann B, Haimov Y, Segal E, Amit R (2019) Designing bacterial chemotactic receptors guided by photonic femtoliter well arrays for quantifiable, label-free measurement of bacterial chemotaxis. ACS Biomater Sci Eng 5:603-612. https://doi. org/10.1021/acsbiomaterials.8b01429

157. Luu RA, Schomer RA, Brunton CN, Truong R, Ta AP, Tan WA, Parales JV, Wang Y-J, Huo Y-W, Liu S-J, Ditty JL, Stewart V, Parales RE (2019) Hybrid two-component sensors for identification of bacterial chemoreceptor function. Appl Environ Microbiol. https://doi.org/10.1128/AEM.01626 $-19$

\section{Publisher's Note}

Springer Nature remains neutral with regard to jurisdictional claims in published maps and institutional affiliations.

\section{Submit your manuscript to a SpringerOpen ${ }^{\circ}$ journal and benefit from:}

- Convenient online submission

- Rigorous peer review

- Open access: articles freely available online

- High visibility within the field

- Retaining the copyright to your article

Submit your next manuscript at springeropen.com 